\title{
Evaluation of Molecular and Phenotypic Diversity in Relation to Heterosis in Some Tomato Lines Under Different Climatic Conditions Abd El-Aziz, M. H. ${ }^{1 *}$; S. M. Farid ${ }^{2}$ and Sara A. A. Elkomey ${ }^{2}$ \\ ${ }^{1}$ Genet. Dep. Fac. of Agric., Mansoura Univ., Mansoura, Egypt. \\ ${ }^{2}$ Horticultural Research Inst., Agri. Res. Center, Egypt.
}

- Corresponding author; E-mail: mohahassan2005@gmail.com

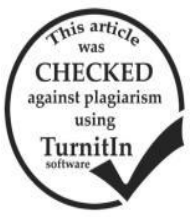

\begin{abstract}
Five tomato inbred lines (Solanum lycopersicum L.,) obtained from five widespread varieties in Egypt were used in this study to assess genetic diversity among them. Seven RAPD and six ISSR primers were succeeded in generating reproducible and reliable amplicons. Although, the RAPD technique was better than ISSR technique in assessment for molecular diversity and discrimination capacity among lines. The Rp value for RAPD technique was 13.7 which was higher than 8.1 of ISSR technique. However, both techniques were suitable tools for detecting reproducible polymorphic patterns and confirmed to be valid in discrimination among lines through the various specific markers of 27 and 18 markers in RAPD and ISSRs, respectively. These markers succeeded in distinguishing each lines and divided them into three groups in cluster analysis with different degrees of MD which ranged from 0.198 to 0.441 with a mean of 0.343 . Moreover, 22 various traits estimated for all lines under two different climatic seasons of the summer season of 2014 and the winter season 2015 also which succeeded in description of phenotypic diversity and heterogeneity within lines which divided accordingly into two main groups with different degrees of PD ranged from 0.081 to 0.428 with mean of 0.236 . However, insignificant correlations were found among the distances computed based on these two types of genetic diversity as well as, the correlation relationships among these distances and heterosis for most studied traits were not significant. This requires evaluating genetic diversity for lines which are used as parents in breeding improvement programs of tomato at more than location and under different climatic conditions. Also, through a more number of variable molecular markers and also depending on a more number of phenotypic traits. Hence, achieving the desired goal from this evaluation, which is the prediction of heterosis for all important traits and which will lead to provision of strenuous efforts to assess hybrids in most breeding programs.
\end{abstract}

Keywords:, Tomato, Genetic Diversity, RAPD, ISSRs, Molecular distance, Phenotypic distance, Cluster analysis, Heterosis.

\section{INTRODUCTION}

Tomato (Solanum lycopersicum L., previously Lycopersicon esculentum Mill., $2 \mathrm{n}=24$ ), is a major vegetable crop for the world's population including Egypt (AVRDC-The World Vegetable Center 2009) (Mansour et al., 2010). This plant has been genetically and extensively studied in terms of molecular genetics, genomics and plant development. These studies help in developing genetic map for tomato which was constructed in the early 1990s using RFLP markers (Tanksley et al., 1992). Germplasm diversity and genetic relationships among breeding materials are valuable aid in strategies of tomato improvement (Evgenidis et al., 2011). The main goals of tomato breeders are higher productivity, better tolerance to biotic and abiotic stresses and increased nutritional and health value of the fruit which require a better understanding and management of tomato genetic resources diversity. The information on molecular and phenotypic diversity among different genotypes is of great importance in vegetable crops improvement. Assessment of genetic diversity and relatedness between different genotypes are prerequisite towards effective utilization of heterosis and the protection of plant genetic resources (Weising et al., 1995).

To evaluate and estimate the genetic diversity of plants, various methods would be used including morphological, biochemical and molecular markers (Henareh et al., 2015). It was recognized that genetic diversity studies based on molecular markers reveal patterns of diversity in plants that are obscured by the complexities of pedigree records (Drinic et al., 2012). On the other hand, morphological markers are often used for genetic diversity analysis and evaluate genetic relationships (Nikoumanesh et al., 2011; Babic et al., 2012).

Morphological or phenotypic traits are commonly used to assessment of genetic diversity since they provide a simple way of quantifying genetic variation (Beuningen \& Busch,1997). Moreover, the use of molecular markers to overcome many of the limitations of morphological and pedigree information based-genetic diversity analysis (Gupta et al., 1999), where molecular markers techniques have proven to be valuable tools in the evaluation of genetic variation both within and between species (Powell et al., 1996). So, the use of a combination of morphological and molecular markers to evaluate genetic diversity in plant is the best and the most common (Khadivi-Khub et al., 2008; Nikoumanesh et al., 2011).

Various kinds of molecular marker techniques would be used to estimate genetic diversity in vegetable crops, especially Tomato such as RFLP (restriction fragment length polymorphism), RAPD (random amplified polymorphic DNA), ISSRs (inter-simple sequence repeats) and IRAP (inter-retrotransposon amplified polymorphism). Many previous studies reported that the application of both RAPD and ISSRs techniques have an important potential to provide useful tools for detection of genetic differences among tomato varieties. RAPD technique based on polymerase chain reaction (PCR) using short arbitrary primers for amplification of discrete regions of the genome (Williams et al., 1990). While, ISSR technique based on polymerase chain reaction (PCR) using SSR (simple sequence repeats) primers for amplification of regions between two inverted SSRs made up of the same sequence. ISSR was first used by Zietkiewicz et al. 
(1994) to rapidly differentiate among closely related individuals. Both methods provide quick, reliable and informative data for genotyping tomato cultivars (Nagoka and Ogihara, 1997; Levi and Rowland, 1997; Mansour et al., 2009; Mansour et al., 2010; Hassan et al., 2013 and Srinivasan et al., 2013).

The comparison between molecular and morphological markers concluded that both marker systems only partially reflect genetic relationships among different genotypes. Therefore, the combined analysis between these systems provides a better assessment for genetic diversity among genotypes (Nagy et al., 2003). Also, a combination of traditional breeding and molecular markers would facilitate simultaneous selection of several traits like yield, yield component, fruit quality, tolerance to biotic and abiotic stresses (Srinivasan et al., 2013).

Thus, the aim of the present investigation was to assess for genetic diversity using estimating molecular and phenotypic distances among some tomato lines. Also, to evaluate the correlation relationships between these distances and estimated heterosis resulted from the hybrids that obtained through crossing these lines under different climatic conditions.

\section{MATERIALS AND METHODS}

\section{Plant materials}

Five tomato varieties belong to species (Lycopersicon esculentum Mill) were used in this study and are shown in Table 1. The seeds of these varieties were obtained from the National Gene Bank.

Individual plants from each variety were cultivated and self pollinated at the beginning of 2012 for three generations at a private farm in Gamasa, Dakahlia, Egypt, to obtaine an inbred line from each variety.

\section{Molecular diversity evaluation of lines}

For molecular diversity evaluation, bulked DNA extraction was performed from seed samples of obtained lines using DNeasy Mini Kit (QIAGEN). Bulked DNA extraction from each inbred line was used as a template for PCR amplification was carried out in Techni TC-512 PCR System using 7 RAPD and 6 ISSR primers (Operon Technology, USA). These primers used in detecting polymorphism among studied lines are presented in Table 2. Amplification reactions were performed in 30- $\mu$ l volume tubes according Williams et al., (1990) containing the following: $3.0 \mu \mathrm{l}$ of dNTPs

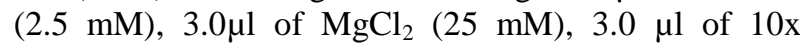
buffer, $2.0 \mu \mathrm{l}$ of primer $(10 \mathrm{pmol}), 0.2 \mu \mathrm{l}$ of $\mathrm{Taq}$ polymerase $(5 \mathrm{U} / \mu \mathrm{l}), 2.0 \mu \mathrm{l}$ of template DNA $(25 \mathrm{ng} / \mu \mathrm{l})$, and $16.8 \mu \mathrm{l}$ of sterile $\mathrm{ddH}_{2} \mathrm{O}$. The reaction in RAPD Technique was programmed for one cycle at $94^{\circ} \mathrm{C}$ for 4 min followed by 45 cycles of $1 \mathrm{~min}$ at $94^{\circ} \mathrm{C}, 1 \mathrm{~min}$ at $37^{\circ} \mathrm{C}$, and $2 \mathrm{~min}$ at $72^{\circ} \mathrm{C}$. The reaction was finally stored at $72^{\circ} \mathrm{C}$ for $10 \mathrm{~min}$. Also, the amplification reaction in ISSR technique was programmed for one cycle at $94^{\circ} \mathrm{C}$ for $4 \mathrm{~min}$ followed by 45 cycles of $1 \mathrm{~min}$ at $94^{\circ} \mathrm{C}, 1 \mathrm{~min}$ at $57^{\circ} \mathrm{C}$, and $2 \mathrm{~min}$ at $72^{\circ} \mathrm{C}$. The reaction was finally stored at $72^{\circ} \mathrm{C}$ for $10 \mathrm{~min}$. $15 \mu \mathrm{l}$ from each DNA amplified products, were loaded and separated on a 1.5 $\%$ agarose gel with $1.5 \mathrm{~kb}$ ladder markers (mix was used as standard DNA with molecular weights of 1.5, 1.0, $0.9,0.8,0.7,0.6,0.5,0.4,0.3,0.2$ and $0.1 \mathrm{~kb}$ ). The run was performed for about $30 \mathrm{~min}$ at $80 \mathrm{~V}$ in mini submarine gel BioRad. RAPD and ISSR PCR products banding patterns were analyzed by GelAnalyzer3 software. These DATA scoring amplicons (pieces of DNA that has been synthesized using amplification techniques) as present (1) or absent (0) for each primer and entered in the form of a binary data matrix. The efficiency of each primer to differentiate between cultivars was assessed by value known as resolving power (Rp) (Hasnaoui et al., 2010), this value was calculated according to Prevost and Wilkinson (1999). Based on binary data matrix, the relationships among obtained lines as revealed by dissimilarity matrices and dendrograms were done using Nei \& Li coefficients (Nei \& Li, 1979) by computational software MVSP 3.1. From this matrix, the molecular distances MD were estimated between all lines.

\section{Phenotypic diversity evaluation of lines}

In parallel with the previous work, the obtained lines were planted during the summer season of 2013. At the flowering time, 20 single crosses including reciprocals (10 direct crosses and their reciprocals) were made among lines according to complete diallel crosses mating design. After that, all genotypes were evaluated in different climatic conditions through the summer season of 2014 and winter season 2015. Data were recorded for 22 variable traits on ten guarded and labled randomly chosen plants per plot for all entries in the two growing seasons. These traits were: three vegetative traits (Plant height P.H, number of primary branches per plant N.P.B and leaf area L.A), four earliness traits (days to first flowering D.F.F, number of nodes carrying first flowering branch N.N.F.F.B, number of fruits per plot for the first three pickings NF3P/plot and weight of fruits per plot for the first three pickings WF3P/plot), two yield component traits (total number of fruit per plot $\mathrm{TNF} /$ plot and total weight of fruits per plot TWF/plot), six fruit characteristics (number of locules per fruit N.L.F, fruit firmness F.F, pericarp thickness P.T, fruit length FL $\mathrm{cm}$ and shape index SI $\mathrm{cm}$ ) and seven chemical traits ( chlorophyll a CLa, chlorophyll b $\mathrm{CLb}$, total chlorophyll CLt, carotene Caro., total soluble solids T.S.S, vitamin C content VC and lycopene content Lyco.).

Table 1: Information of different tomato lines used in this study.

\begin{tabular}{lccccc}
\hline Variety & Country of origin & Obtained & \multicolumn{3}{c}{ Characteristics of varieties } \\
inbred line & Fruit size and shape & Growth habit & Maturity \\
\hline Advantage2 & American & P1 & Medium and cylindrical & Semi determinate & Early \\
Cherry & Egypt & P2 & Small and cylindrical & Standing & Early \\
Fatma & Indonesia & P3 & Medium and tall & Semi determinate & Medium \\
Edkaway & Egypt & P4 & Determinate & Late \\
Castle Rock & American & P5 & Large & Determinate & Medium \\
\hline
\end{tabular}


Based on data of mean performances of these traits for lines under different climatic conditions in two season and combined data, phenotypic distance PD between five parental lines were computed using computational software MVSP 3.1 by equation of normalized Euclidean morphological distance according to RoldanRuiz et al., (2001).

\section{Correlation relationships}

Simple correlations using the computational software Minitab 17 were used to explain relationships between molecular distances (MD) and phenotypic distances (PD) and also with heterosis over mid-parents $\left(\mathrm{H}_{\mathrm{MP}} \%\right)$ and heterosis over better parent $\left(\mathrm{H}_{\mathrm{BP}} \%\right)$ (Rizkalla et al., 2012 \& El-Zanaty et al., 2013).

\section{RESULTS AND DISCUSSION}

Molecular diversity evaluation PCR amplification patterns of RAPD and ISSRs

The seven RAPD and six ISSR primers used in this investigation were succeeded in generating reproducible and reliable amplicons as shown in Figures from 1 to 4 . The number of polymorphic amplicons, percentage of polymorphism and resolving power obtained by analyzing five Tomato lines were presented in Table 2. A total of 121 amplicons, 96 of them were polymorphic where, the highest number of amplicons were generated by RAPD primer OP- A11 (14), while generated the lowest number (five) by ISSR primer $\mathrm{Hb}$ 11. Molecular size (bp) of these amplicons ranging from 164 to $1429 \mathrm{bp}$ and from 123 to $1295 \mathrm{bp}$ were amplified using RAPD and ISSRs techniques, respectively. The percentage of polymorphism ranging from 50 to $90 \%$ and from 60 to $100 \%$ were calculated for RAPD and ISSRs techniques, respectively. Also, the resolving power values which ranged between 10.0 to 17.6 and 6.0 to 9.2 were computed for RAPD and ISSRs techniques, respectively. Moreover, various specific markers were generated using all RAPD and ISSRs techniques. 45 out of 121 amplicons (37.2\%) were found to be useful as unique markers.

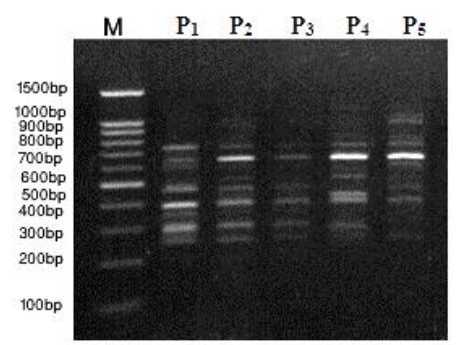

OP-A11

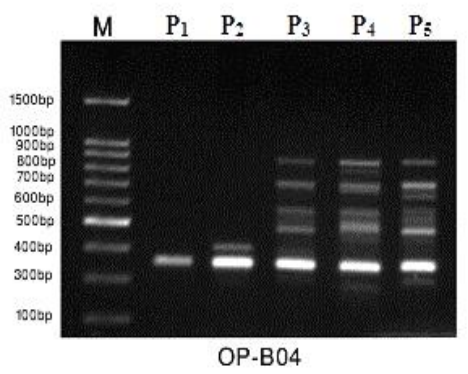

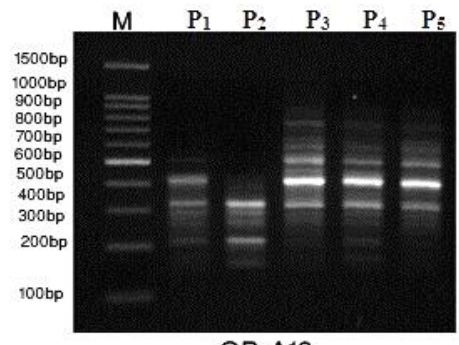

OP-A13

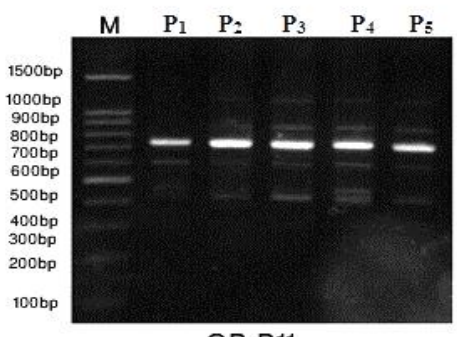

OP-B11

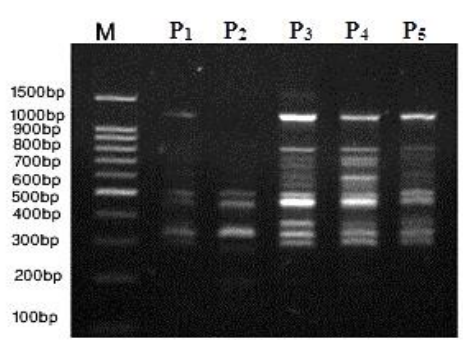

OP-B01

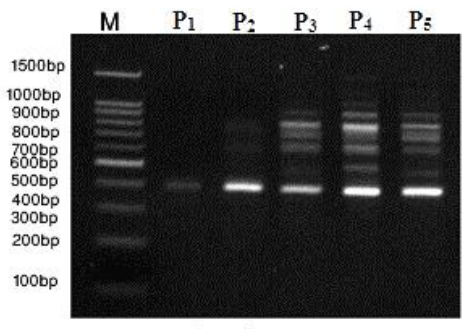

OP-C09

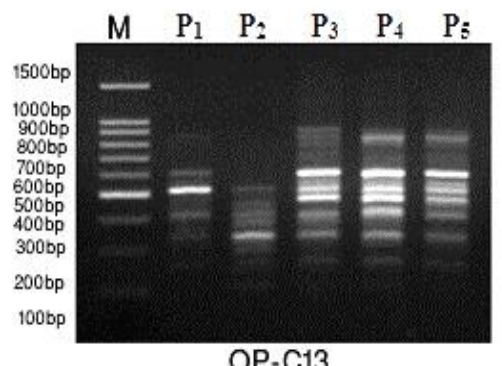

OP-C13

Figure (1) : Banding patterns of RAPD-PCR products for lines of tomato produced with seven primers. M, $1.5 \mathrm{~kb}$ ladder and lanes 2 to 6 represent the five lines. 


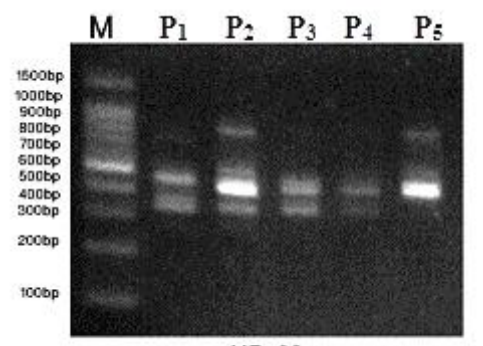

HB-08

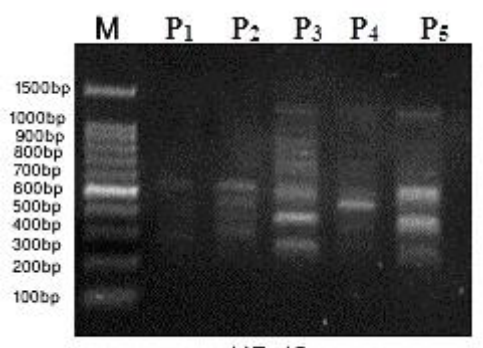

HB-12

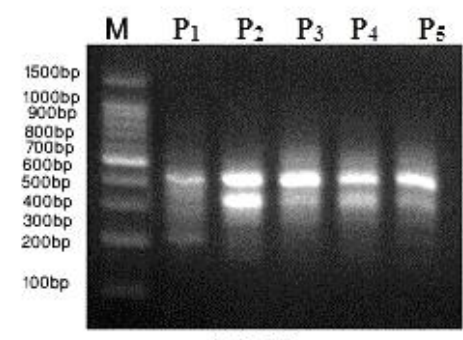

HB-10

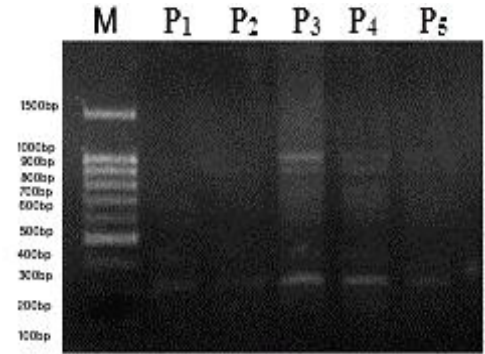

HB-13

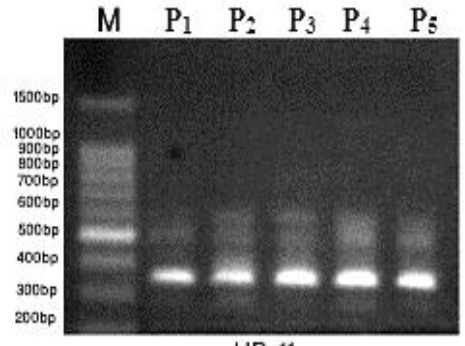

HB-11

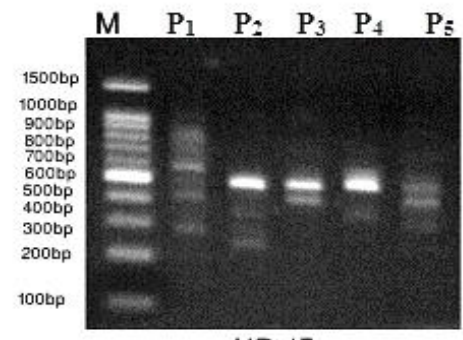

HB-15

Figure (2) : Banding patterns of ISSR-PCR products for lines of tomato produced with six primers. M, $1.5 \mathrm{~kb}$ ladder and lanes 2 to 6 represent the five lines.

Table 2: List of primers for RAPD and ISSRs techniques, number of amplicons types, total number of amplicons, percentage of polymorphism and resolving power obtained by analyzing different Tomato lines.

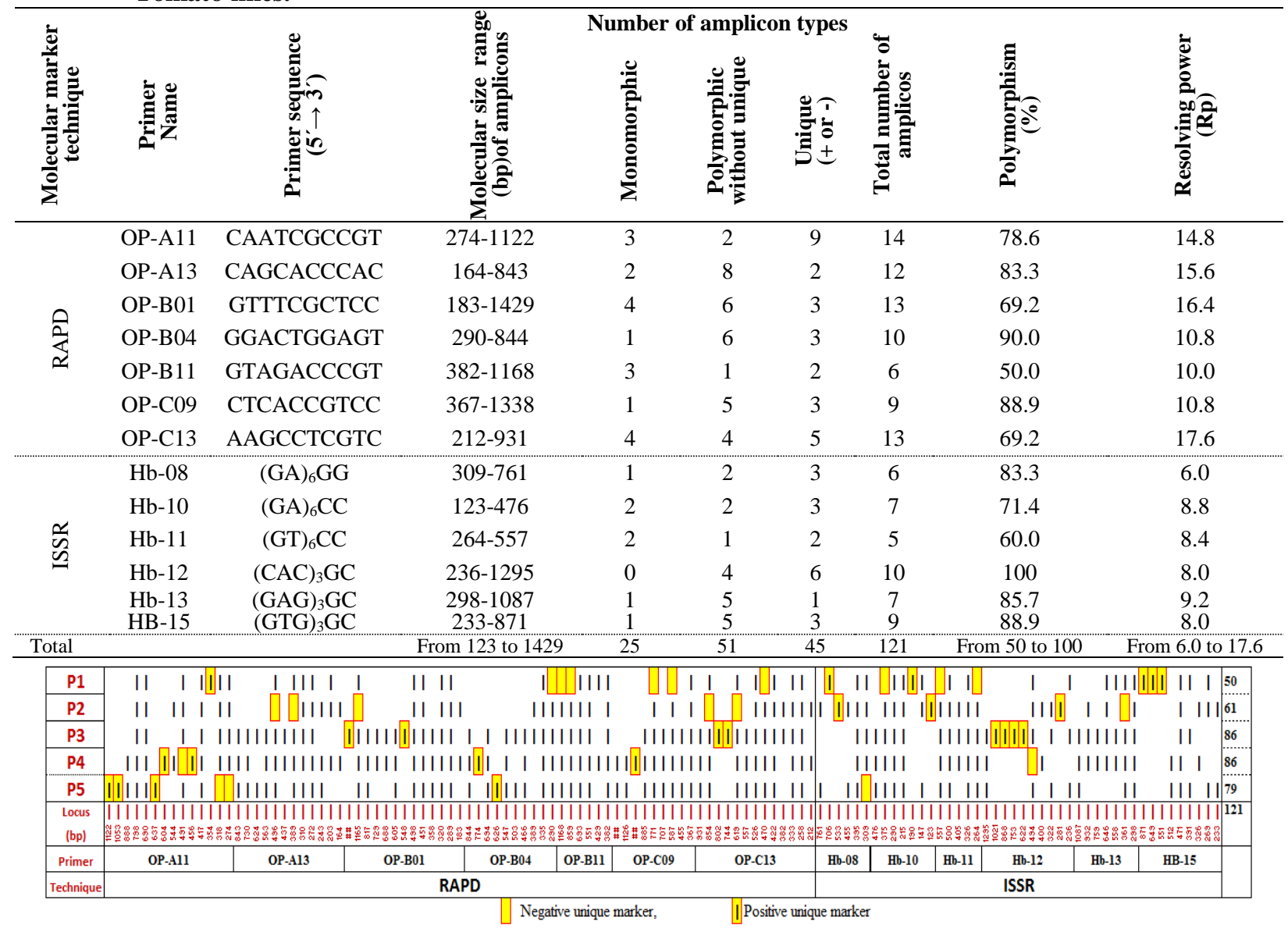

Figure (3): DNA-profile representation of RAPD and ISSR markers of Tomato lines based on 121 amplicons 45 of them were marker loci according to Adhikari et al., (2015).

Lines identification by unique markers

Also, Table 2 and Figure 3 indicates that all

RAPD and ISSR primers generated unique markers. The highest number of unique markers (nine) generated by
RAPD primer OP-A11, while the lowest number (one) generated by ISSR primer $\mathrm{Hb}-13$.

In addition, it is clear from Table 3 and Figure 3 that all studied lines were characterized by unique markers. 
Table 3: Different Tomato genotypes characterized by unique positive and/or negative RAPD and ISSR markers, marker size and total number of markers identifying each genotype.

\begin{tabular}{|c|c|c|c|c|c|c|c|c|}
\hline \multirow[b]{2}{*}{$\begin{array}{l}\text { Molecular } \\
\text { marker } \\
\text { technique }\end{array}$} & \multirow[b]{2}{*}{ Inbred line } & \multicolumn{3}{|c|}{ Unique positive markers } & \multicolumn{3}{|c|}{ Unique negative markers } & \multirow[b]{2}{*}{$\begin{array}{c}\text { Total } \\
\text { markers }\end{array}$} \\
\hline & & $\begin{array}{c}\text { Size of } \\
\text { marker loci } \\
\text { (bp) }\end{array}$ & Primer & $\begin{array}{c}\text { Total } \\
\text { positive } \\
\text { markers/ } \\
\text { Line }\end{array}$ & $\begin{array}{c}\text { Size of } \\
\text { marker loci } \\
\text { (bp) }\end{array}$ & Primer & $\begin{array}{l}\text { Total } \\
\text { negative } \\
\text { markers/ } \\
\text { Line }\end{array}$ & \\
\hline \multirow{5}{*}{ RAPD } & $\mathrm{P} 1$ & 354 & OP-A11 & 1 & $\begin{array}{c}290 \\
859 \\
1168 \\
587 \\
771 \\
470\end{array}$ & $\begin{array}{l}\text { OP-B04 } \\
\text { OP-B11 } \\
\text { OP-C09 } \\
\text { OP-C13 }\end{array}$ & 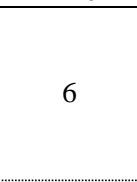 & 7 \\
\hline & $\mathrm{P} 2$ & -- & -- & -- & $\begin{array}{c}389 \\
496 \\
1165 \\
619 \\
854\end{array}$ & $\begin{array}{l}\text { OP-A13 } \\
\text { OP-B01 } \\
\text { OP-C13 }\end{array}$ & 5 & 5 \\
\hline & P3 & $\begin{array}{c}548 \\
1429 \\
744 \\
802\end{array}$ & $\begin{array}{l}\text { OP-B01 } \\
\text { OP-C13 }\end{array}$ & 4 & -- & -- & -- & 4 \\
\hline & $\mathrm{P} 4$ & $\begin{array}{c}456 \\
604 \\
774 \\
1023\end{array}$ & $\begin{array}{l}\text { OP-A11 } \\
\text { OP-B04 } \\
\text { OP-C09 }\end{array}$ & 4 & 491 & OP-A11 & 1 & 5 \\
\hline & P5 & $\begin{array}{c}637 \\
1053 \\
1122 \\
626\end{array}$ & $\begin{array}{l}\text { OP-A11 } \\
\text { OP-B04 }\end{array}$ & 4 & $\begin{array}{l}274 \\
318\end{array}$ & OP-A11 & 2 & 6 \\
\hline \multirow{5}{*}{ ISSR } & $\mathrm{P} 1$ & $\begin{array}{l}706 \\
190 \\
551 \\
649 \\
871 \\
\end{array}$ & $\begin{array}{l}\text { HP-08 } \\
\text { HP-10 } \\
\text { HP-15 }\end{array}$ & 5 & $\begin{array}{l}375 \\
\\
264 \\
557\end{array}$ & HP-11 & 3 & 8 \\
\hline & $\mathrm{P} 2$ & $\begin{array}{l}533 \\
123 \\
281\end{array}$ & $\begin{array}{l}\text { HP-08 } \\
\text { HP-10 } \\
\text { HP-12 }\end{array}$ & 3 & 361 & HP-15 & 1 & 4 \\
\hline & P3 & $\begin{array}{c}622 \\
753 \\
868 \\
1021\end{array}$ & HP-12 & 4 & -- & -- & -- & 4 \\
\hline & P4 & -- & -- & -- & 494 & $\mathrm{HP}-12$ & 1 & 1 \\
\hline & P5 & -- & -- & -- & 309 & HP-08 & 1 & 1 \\
\hline
\end{tabular}

On the other hand, evident from the results presented in Table 3 that inbred line P1 obtained from the American cultivar (Advantage2) it was distinguished through the highest number of unique markers (seven and eight using RAPD and ISSRs techniques, respectively). While the lowest number of unique markers (five and one using RAPD and ISSRs techniques, respectively) was scored for the inbred line P4 that obtained from the Egyptian cultivar (Edkaway). Also, the inbred line P3 obtained from the Indonesian cultivar (Fatma) was the most showed positive unique markers (four using each technique), while did not show any negative unique markers using both techniques.

This shows that the American inbred line P1 was more to demonstrate the unique molecular markers (15) in total, while the Indonesian inbred line P3 were more to demonstrate the positive unique markers (8) in total. Also, confirms the success of both techniques to distinguish all studied lines of tomato through a large and diverse number of unique markers that characterized each inbred line from the other, as shown DNA-profile diagram (Figure 3). This diagram indicated that the total amplicons for each inbred line were 50, 61, 86, 86, and 79 for P1, P2, P3, P4 and P5, respectively, where they discriminated these lines by number of the positive unique markers as follows 6,3 , 8, 4 and 4, for P1, P2, P3, P4 and P5, respectively.
All previous results demonstrate the success of RAPD and ISSRs techniques in the detection reproducible polymorphic patterns and confirmed to be valid in discriminating between studied lines of tomato through various specific markers distinguish each of these lines. These were in harmony with what was illustrated previously in tomato by Mansour et al. (2010), Hassan et al. (2013) and Srinivasan et al. (2013).

\section{Comparison of RAPD and ISSR techniques}

While RAPD markers cover the whole genome for amplification, ISSR markers amplifies the sequence between two microsatellites. Hence, the polymorphisms reflect the genetic diversity of these sequences of the genome. And in comparison between these molecular marker techniques applied in this study as shown in Table 4, it is indicated that the RAPD technique produced the highest number of amplicons (77). The number of polymorphic amplicons produced by different primers was 59 and 37 for RAPD and ISSRs, respectively. The average numbers of polymorphic amplicons produced by these primers were 8.4 and 6.2 for RAPD and ISSRs, respectively. Among the techniques used, RAPD showed 75.6\% of polymorphism; ISSR techniques showed $81.6 \%$ polymorphism. These results were in agreement with those obtained by Srinivasan et al. (2013) in Tomato. 
Table 4: Comparison of genetic diversity assessment by RAPD and ISSR analysis

\begin{tabular}{|c|c|c|c|c|c|c|c|c|c|c|c|}
\hline \multirow{3}{*}{ 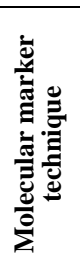 } & \multirow{3}{*}{ 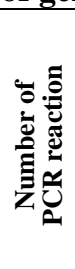 } & \multicolumn{6}{|c|}{ Gel Polymorphism } & \multirow{3}{*}{ 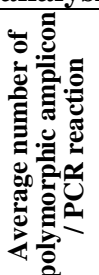 } & \multirow{3}{*}{ 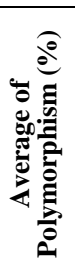 } & \multirow{3}{*}{ 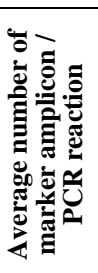 } & \multirow{3}{*}{ 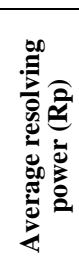 } \\
\hline & & & \multicolumn{3}{|c|}{ Total marker amplicon } & & $\overline{0}=$ & & & & \\
\hline & & 递 & 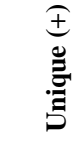 & 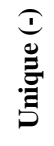 & है & 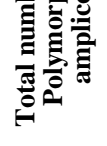 & 吾䓂 & & & & \\
\hline RAPD & 7 & 32 & 13 & 14 & 27 & 5 & 77 & 8.4 & 75. & 3. & 13.7 \\
\hline ISSR & 6 & 19 & 12 & 6 & 18 & 37 & 4 & 6.2 & 81 & 3. & \\
\hline Total & 13 & 51 & 25 & 20 & 45 & 96 & 121 & 7.4 & 79.3 & 3.46 & 10.9 \\
\hline
\end{tabular}

So these techniques may a have a better application in diversity analysis studies.

data, the highest and lowest MD were 0.500 and 0.216 between lines (P1 and P4) and (P3 and P4), Moreover, the average values of resolving power ( $\mathrm{Rp}$ ) computed for all primer used in each technique. These values are characteristic of the primers which reflects overall suitability of a molecular marker technique for the purpose of molecular identification, as it is related to the number of genotypes discriminated by that primer (Prevost and Wilkinson, 1999). Also as shown in Table 4, the Rp values for RAPD and ISSR techniques were 13.7 and 8.1, respectively.

All of these, indicates that the RAPD technique was better than ISSR technique in discrimination capacity for studied lines and assessment for genetic diversity among them. These findings were in harmony with that illustrated previously by some studies, such as Tanyolac (2003) in barley and Mukherjee et al. (2013) in allium, who indicated that RAPD technique generated more amplicons, its discriminating capacity was also significantly higher than that of ISSR. In the contrary, many studies were shown that ISSRs technique is more effective in the evaluation of the genetic diversity than RAPD technique, these studies such as, Parsons et al. (1997) in Rice; Goulao and Oliveira (2001) in Apple; Chowdhury et al. (2002) in Chickpea ; Fernández et al. (2002) in Barley; Hussein et al. (2005) in Date palm; Abd El-Hady et al. (2010) in Vigna and Abd El-Aziz and Habiba (2016) in Canola.

\section{Molecular distances}

The results presented in Table 5 showed that Molecular distance (MD) matrix based on RAPD, ISSRs, and combined data. The highest MD according to RAPD data was between lines P1 and P5 (0.429), while the lowest MD according to the same data was between lines P3 and P5 (0.168). According to ISSR

Table (5): Molecular distances between five Tomato lines based on RAPD, ISSR and combined data.

\begin{tabular}{|c|c|c|c|c|c|}
\hline & P1 & $\overline{\mathbf{P 2}}$ & $\overline{\mathbf{P 3}}$ & $\mathbf{P 4}$ & Technique \\
\hline \multirow{3}{*}{ P2 } & 0.312 & & & & RAPD \\
\hline & 0.489 & & & & ISSR \\
\hline & 0.387 & & & & Comb. \\
\hline \multirow{3}{*}{ P3 } & 0.402 & 0.376 & & & RAPD \\
\hline & 0.429 & 0.407 & & & ISSR \\
\hline & 0.412 & 0.388 & & & Comb. \\
\hline \multirow{3}{*}{ P4 } & 0.413 & 0.347 & 0.190 & & RAPD \\
\hline & 0.500 & 0.347 & 0.216 & & ISSR \\
\hline & 0.441 & 0.347 & 0.198 & & Comb. \\
\hline \multirow{3}{*}{ P5 } & 0.429 & 0.422 & 0.168 & 0.186 & RAPD \\
\hline & 0.422 & 0.320 & 0.308 & 0.362 & ISSR \\
\hline & 0.426 & 0.386 & 0.212 & 0.236 & Comb. \\
\hline
\end{tabular}
respectively. While, the highest and lowest $\mathrm{MD}$ based on combined data were 0.441 and 0.198 among the same pairs from lines according to ISSR data.

\section{Combined analysis with RAPD and ISSRs techniques}

There is no doubt that the reliability of RAPD and ISSRs techniques may be improved by using more primers and this efficiency can be improved depending on the combined results of these techniques. This is due to the combined results may provide more accurate information on the genetic diversity (Abd El-Hady et al., 2010; Onamu et al., 2016; Abd El-Aziz and Habiba, 2016). Accordingly, cluster analysis for five lines of tomato were performed based on the molecular distances (MD) from combined data of RAPD and ISSRs techniques (Figure 4).

UPGMA clustering dendrogram for five Tomato lines based on MD values as shown in Figure 4, indicated that these lines could be divided into three groups with different degrees of MD (ranged from 0.198 to 0.441 with mean 0.343 ). The first and second group (A and B) is comprised by inbred line $\mathrm{P} 1$ and $\mathrm{P} 2$, respectively, while the third group (C) comprises the other three lines. This group included two subgroups (d) and (e), the first subgroup (d) included the two lines P3 and $\mathrm{P} 4$ as well as, the other subgroup (e) involved one inbred line (P5). This indicates that the cluster analysis based on combined data of MD for RAPD and ISSRs techniques succeeded in description of genetic diversity and heterogeneity within studied lines. The results also, indicates the presence of clear variance between all studied lines, this reflects the agronomic diversity within these lines (Hassan et al., 2013).

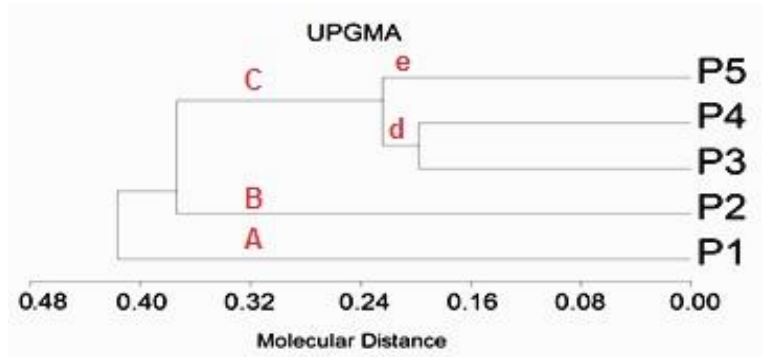

Figure (4): UPGMA clustering dendrogram for five Tomato lines based on MD from combined data of RAPD and ISSRs techniques, according Vaillancourt et al., 1995. 


\section{Phenotypic diversity evaluation}

Phenotypic traits also commonly used in assessment of genetic diversity, this is very important in plant breeding and is essential to meet the various goals such as producing cultivars with increased yield, desirable quality, pest and disease resistance and wider adaption (Nevo et al. 1982). To achieve this purpose, Euclidean distance statistics may be applied for such study. This method measures the phenotypic distance (PD) based on a number of traits between two lines. These distances depend on the differences between the means with respect to the pooled effect of all traits between different lines.

Because of many number of mean performance Tables for all studied traits under two different climatic conditions, these Tables have been abbreviated as shown in Table 6. These abbreviations were recorded in the form of the extent values ranging from the lowest and highest value. In the same way, med and better parent heterosis were recorded in Table 7 , these values were calculated as the percentage of deviation of F1 mean from the mean of two parents and the higher parent, respectively.

Based on results for analysis of variance (data not shown) for all studied traits, highly significant differences among all evaluated genotypes in this study
(Inbred line and its hybrids) were found, except D.F.F trait in combined data from the two climatic conditions. This refers to the reliability of estimates of the studied traits in assessment of phenotypic diversity among studied lines. For assessment of phenotypic diversity among studied lines, the phenotypic distances (PD) between all pairs of studied lines were computed according to the values of mean performance for all studied traits.

Clustering pattern of five Tomato lines based on phenotypic distances

Data of phenotypic distances (PD) were presented in Table 8, and indicated that the highest PD values were between the lines $\mathrm{P} 2$ and $\mathrm{P} 4$ in season 1,2 and combined data as follows: $0.480,0.438$ and 0.428 , respectively. While, the lowest $\mathrm{PD}$ values were between the lines P2 and P3 in season 1, 2 and combined data as follows: $0.053,0.115$ and 0.081 , respectively. This convergence between results of the two seasons and combined data, refers to the reliability of the combined results in providing enough information on the phenotypic diversity. Accordingly, cluster analysis for five lines of tomato were performed based on the phenotypic distances (PD) from combined data of the two different climatic seasons (Figure 5).

Table 6: Range of the mean performance values (above) of studied lines and their hybrids (below) for all studied traits

\begin{tabular}{|c|c|c|c|c|c|c|c|c|c|c|c|c|}
\hline \multirow[b]{2}{*}{ Trait } & \multicolumn{6}{|c|}{ Mean performance of the parental lines } & \multicolumn{6}{|c|}{ Mean performance of the Hybrids } \\
\hline & Low. & Hig. & Low. & Hig. & Low. & b. & Low. ${ }^{1}$ & S. Hig. & Low. $^{2}$ & S. Hig. & Low. & b. \\
\hline PH & $\begin{array}{c}60.67 \\
(\mathrm{P} 1)\end{array}$ & $\begin{array}{c}105.67 \\
(\mathrm{P} 2)\end{array}$ & $\begin{array}{c}64.33 \\
(\mathrm{P} 4)\end{array}$ & $\begin{array}{c}103.67 \\
(\mathrm{P} 2)\end{array}$ & $\begin{array}{c}62.67 \\
(\mathrm{P} 1)\end{array}$ & $\begin{array}{c}104.67 \\
(\mathrm{P} 2)\end{array}$ & $\begin{array}{c}63.33 \\
(\mathrm{P} 5 \times \mathrm{x} 4)\end{array}$ & $\begin{array}{c}104.33 \\
\text { (P1xP4) }\end{array}$ & $\begin{array}{c}64.33 \\
(\mathrm{P} 5 \times \mathrm{x} 4)\end{array}$ & $\begin{array}{c}105.00 \\
(\mathrm{P} 2 \mathrm{xP} 4)\end{array}$ & $\begin{array}{c}63.83 \\
(\mathrm{P} 5 \times \mathrm{P} 4)\end{array}$ & $\begin{array}{l}103.50 \\
\text { (P3xP1) }\end{array}$ \\
\hline N.P.B & $\begin{array}{c}17.33 \\
(\mathrm{P} 3)\end{array}$ & $\begin{array}{c}24.00 \\
(\mathrm{P} 2)\end{array}$ & $\begin{array}{c}17.00 \\
(\mathrm{P} 1)\end{array}$ & $\begin{array}{c}21.67 \\
(\mathrm{P} 2)\end{array}$ & $\begin{array}{c}17.33 \\
(\mathrm{P} 1)\end{array}$ & $\begin{array}{c}23.33 \\
(\mathrm{P} 5)\end{array}$ & $\begin{array}{c}18.33 \\
(\mathrm{P} 5 \times \mathrm{xP} 4)\end{array}$ & $\begin{array}{c}25.33 \\
(\mathrm{P} 1 \mathrm{xP} 2)\end{array}$ & $\begin{array}{c}18.67 \\
(\mathrm{P} 2 \times \mathrm{x} 3)\end{array}$ & $\begin{array}{c}24.00 \\
(\mathrm{P} 1 \mathrm{xP} 2)\end{array}$ & $\begin{array}{c}18.66 \\
(\mathrm{P} 5 \times \mathrm{x} 4)\end{array}$ & $\begin{array}{c}24.66 \\
\text { (P1xP2) }\end{array}$ \\
\hline L.A & $\begin{array}{l}9.27 \\
(\mathrm{P} 2)\end{array}$ & $\begin{array}{c}26.95 \\
(\mathrm{P} 3)\end{array}$ & $\begin{array}{c}10.21 \\
(\mathrm{P} 1)\end{array}$ & $\begin{array}{c}24.58 \\
(\mathrm{P} 3)\end{array}$ & $\begin{array}{c}10.63 \\
(\mathrm{P} 2)\end{array}$ & $\begin{array}{c}25.76 \\
(\mathrm{P} 3)\end{array}$ & $\begin{array}{c}8.20 \\
(\mathrm{P} 1 \mathrm{xP} 2)\end{array}$ & $\begin{array}{c}21.08 \\
(\mathrm{P} 2 \times \mathrm{x} 5)\end{array}$ & $\begin{array}{c}9.59 \\
(\mathrm{P} 1 \mathrm{xP} 2)\end{array}$ & $\begin{array}{c}22.19 \\
(\mathrm{P} 2 \mathrm{xP5})\end{array}$ & $\begin{array}{c}8.89 \\
(\mathrm{P} 1 x \mathrm{xP})\end{array}$ & $\begin{array}{c}21.63 \\
\text { (P2xP5) }\end{array}$ \\
\hline D.F.F & $\begin{array}{c}95.13 \\
(\mathrm{P} 4)\end{array}$ & $\begin{array}{c}61.53 \\
(\mathrm{P} 3)\end{array}$ & $\begin{array}{c}100.47 \\
(\mathrm{P} 3)\end{array}$ & $\begin{array}{c}87.53 \\
(\mathrm{P} 4)\end{array}$ & $\begin{array}{c}91.33 \\
(\mathrm{P} 4)\end{array}$ & $\begin{array}{c}81.00 \\
(\mathrm{P} 3)\end{array}$ & $\begin{array}{c}86.13 \\
\text { (P3xP5) }\end{array}$ & $\begin{array}{c}73.10 \\
\text { (P1xP4) }\end{array}$ & $\begin{array}{c}99.57 \\
(\mathrm{P} 3 \times \mathrm{x} 4)\end{array}$ & $\begin{array}{c}91.20 \\
\text { (P1xP5) }\end{array}$ & $\begin{array}{c}93.23 \\
\text { (P3xP4) }\end{array}$ & $\begin{array}{c}83.88 \\
\text { (P1xP2) }\end{array}$ \\
\hline N.N.F.F.B & $\begin{array}{c}2.33 \\
(\mathrm{P} 1,4)\end{array}$ & $\begin{array}{l}1.00 \\
(\mathrm{P} 3)\end{array}$ & $\begin{array}{l}2.66 \\
\text { (P3) }\end{array}$ & $\begin{array}{l}1.66 \\
\text { (P4) }\end{array}$ & $\begin{array}{c}2.16 \\
(\mathrm{P} 1,5)\end{array}$ & $\begin{array}{l}1.83 \\
(\mathrm{P} 3)\end{array}$ & $\begin{array}{c}3.00 \\
\text { (P4xP3) }\end{array}$ & $\begin{array}{c}1.66 \\
(\mathrm{P} 1 \times \mathrm{P} 2)\end{array}$ & $\begin{array}{c}3.00 \\
\text { (P4xP3) }\end{array}$ & $\begin{array}{c}1.66 \\
(\mathrm{P} 1 \times \mathrm{P} 2)\end{array}$ & $\begin{array}{c}3.00 \\
(\mathrm{P} 4 \times \mathrm{xP} 3)\end{array}$ & $\begin{array}{c}1.66 \\
(\mathrm{P} 1 \times \mathrm{xP} 2)\end{array}$ \\
\hline NF3P & $\begin{array}{l}15.7 \\
(\mathrm{P} 4)\end{array}$ & $\begin{array}{c}397.00 \\
(\mathrm{P} 2)\end{array}$ & $\begin{array}{l}86.3 \\
(\mathrm{P} 3)\end{array}$ & $\begin{array}{c}320.00 \\
(\mathrm{P} 2)\end{array}$ & $\begin{array}{c}60.00 \\
(\mathrm{P} 4)\end{array}$ & $\begin{array}{c}358.5 \\
(\mathrm{P} 2)\end{array}$ & $\begin{array}{c}72.30 \\
\text { (P5xP4) }\end{array}$ & $\begin{array}{c}659.00 \\
\text { (P1xP5) }\end{array}$ & $\begin{array}{c}62.70 \\
(\mathrm{P} 5 \times \mathrm{P} 1)\end{array}$ & $\begin{array}{c}518.00 \\
\text { (P1xP5) }\end{array}$ & $\begin{array}{c}75.50 \\
(\mathrm{P} 5 \times \mathrm{xP} 4)\end{array}$ & $\begin{array}{l}588.50 \\
\text { (P1xP5) }\end{array}$ \\
\hline WF3P & $\begin{array}{l}4.91 \\
(\mathrm{P} 2)\end{array}$ & $\begin{array}{c}13.14 \\
(\mathrm{P} 5)\end{array}$ & $\begin{array}{l}3.73 \\
(\mathrm{P} 2)\end{array}$ & $\begin{array}{c}29.36 \\
(\mathrm{P} 4)\end{array}$ & $\begin{array}{l}4.31 \\
(\mathrm{P} 2)\end{array}$ & $\begin{array}{c}16.56 \\
(\mathrm{P} 4)\end{array}$ & $\begin{array}{c}3.95 \\
(\mathrm{P} 5 \mathrm{xP} 1)\end{array}$ & $\begin{array}{c}23.91 \\
(\mathrm{P} 2 \times \mathrm{x} 3)\end{array}$ & $\begin{array}{c}3.51 \\
\text { (P5xP1) }\end{array}$ & $\begin{array}{c}24.02 \\
(\mathrm{P} 1 \mathrm{xP} 3)\end{array}$ & $\begin{array}{c}3.73 \\
\text { (P5xP1) }\end{array}$ & $\begin{array}{c}22.85 \\
(\mathrm{P} 2 \times \mathrm{x} 3)\end{array}$ \\
\hline TNF & $\begin{array}{c}286.7 \\
(\mathrm{P} 4)\end{array}$ & $\begin{array}{c}2124.3 \\
(\mathrm{P} 2)\end{array}$ & $\begin{array}{c}357.7 \\
(\mathrm{P} 4)\end{array}$ & $\begin{array}{c}2018.3 \\
(\mathrm{P} 2)\end{array}$ & $\begin{array}{c}322.2 \\
(\mathrm{P} 4)\end{array}$ & $\begin{array}{c}2071.3 \\
(\mathrm{P} 2)\end{array}$ & $\begin{array}{c}289.30 \\
\text { (P5xP4) }\end{array}$ & $\begin{array}{c}3113.3 \\
(\mathrm{P} 1 \times \mathrm{PP} 4)\end{array}$ & $\begin{array}{c}291.00 \\
\text { (P5xP4) }\end{array}$ & $\begin{array}{c}3065.7 \\
\text { (P1xP4) }\end{array}$ & $\begin{array}{c}290.2 \\
\text { (P5xP4) }\end{array}$ & $\begin{array}{c}3089.5 \\
\text { (P1xP4) }\end{array}$ \\
\hline TWF & $\begin{array}{c}21.94 \\
(\mathrm{P} 2)\end{array}$ & $\begin{array}{l}68.27 \\
(\mathrm{P} 5)\end{array}$ & $\begin{array}{c}24.87 \\
(\mathrm{P} 2)\end{array}$ & $\begin{array}{c}101.09 \\
(\mathrm{P} 4)\end{array}$ & $\begin{array}{c}23.41 \\
(\mathrm{P} 2)\end{array}$ & $\begin{array}{c}81.48 \\
(\mathrm{P} 4)\end{array}$ & $\begin{array}{c}31.48 \\
(\mathrm{P} 4 \mathrm{xP} 2)\end{array}$ & $\begin{array}{c}100.92 \\
(\mathrm{P} 2 \times \mathrm{P} 5)\end{array}$ & $\begin{array}{c}32.56 \\
\text { (P5xP3) }\end{array}$ & $\begin{array}{c}104.46 \\
\text { (P2xP5) }\end{array}$ & $\begin{array}{c}30.99 \\
(\mathrm{P} 5 \times \mathrm{x} 3)\end{array}$ & $\begin{array}{c}102.69 \\
\text { (P2xP5) }\end{array}$ \\
\hline N.L.F & $\begin{array}{l}2.00 \\
\text { (P3) }\end{array}$ & $\begin{array}{l}5.00 \\
\text { (P5) }\end{array}$ & $\begin{array}{l}2.00 \\
(\mathrm{P} 3)\end{array}$ & $\begin{array}{l}5.00 \\
\text { (P5) }\end{array}$ & $\begin{array}{l}2.00 \\
\text { (P3) }\end{array}$ & $\begin{array}{l}5.00 \\
\text { (P5) }\end{array}$ & $\begin{array}{c}2.67 \\
(\mathrm{P} 5 \times \mathrm{x} 2)\end{array}$ & $\begin{array}{c}5.67 \\
(\mathrm{P} 3 \times \mathrm{P} 5)\end{array}$ & $\begin{array}{c}3.00 \\
(\mathrm{P} 5 \times \mathrm{x} 2)\end{array}$ & $\begin{array}{c}6.00 \\
\text { (P3xP5) }\end{array}$ & $\begin{array}{c}2.83 \\
(\mathrm{P} 5 \times \mathrm{x} 2)\end{array}$ & $\begin{array}{c}5.83 \\
\text { (P3xP5) }\end{array}$ \\
\hline F.F & $\begin{array}{l}1.23 \\
(\mathrm{P} 2)\end{array}$ & $\begin{array}{l}5.16 \\
(\mathrm{P} 4)\end{array}$ & $\begin{array}{l}1.73 \\
(\mathrm{P} 2)\end{array}$ & $\begin{array}{l}4.63 \\
(\mathrm{P} 4)\end{array}$ & $\begin{array}{l}1.48 \\
(\mathrm{P} 2)\end{array}$ & $\begin{array}{l}4.9 \\
(\mathrm{P} 4)\end{array}$ & $\begin{array}{c}1.66 \\
\text { (P4xP5) }\end{array}$ & $\begin{array}{c}4.53 \\
\text { (P3xP5) }\end{array}$ & $\begin{array}{c}1.83 \\
(\mathrm{P} 3 \times \mathrm{x} 1)\end{array}$ & $\begin{array}{c}4.36 \\
(\mathrm{P} 4 \times \mathrm{P} 1)\end{array}$ & $\begin{array}{c}1.81 \\
(\mathrm{P} 3 \times \mathrm{P} 1)\end{array}$ & $\begin{array}{c}4.43 \\
\text { (P3xP5) }\end{array}$ \\
\hline P.T & $\begin{array}{l}2.48 \\
(\mathrm{P} 2)\end{array}$ & $\begin{array}{l}6.75 \\
(\mathrm{P} 4)\end{array}$ & $\begin{array}{l}2.54 \\
(\mathrm{P} 2)\end{array}$ & $\begin{array}{l}6.00 \\
(\mathrm{P} 4)\end{array}$ & $\begin{array}{l}2.51 \\
(\mathrm{P} 2)\end{array}$ & $\begin{array}{l}6.37 \\
(\mathrm{P} 4)\end{array}$ & $\begin{array}{c}3.34 \\
(\mathrm{P} 5 \mathrm{xP} 2)\end{array}$ & $\begin{array}{c}7.22 \\
\text { (P1xP3) }\end{array}$ & $\begin{array}{c}3.86 \\
(\mathrm{P} 3 \times \mathrm{x} 2)\end{array}$ & $\begin{array}{c}6.45 \\
\text { (P3xP5) }\end{array}$ & $\begin{array}{c}3.81 \\
(\mathrm{P} 3 \times \mathrm{x} 2)\end{array}$ & $\begin{array}{c}6.58 \\
\text { (P1xP3) }\end{array}$ \\
\hline FL & $\begin{array}{l}3.56 \\
(\mathrm{P} 2)\end{array}$ & $\begin{array}{l}5.92 \\
\text { (P4) }\end{array}$ & $\begin{array}{l}2.19 \\
(\mathrm{P} 2)\end{array}$ & $\begin{array}{l}5.44 \\
\text { (P4) }\end{array}$ & $\begin{array}{l}2.87 \\
(\mathrm{P} 2)\end{array}$ & $\begin{array}{l}5.68 \\
\text { (P4) }\end{array}$ & $\begin{array}{c}2.96 \\
\text { (P4xP5) }\end{array}$ & $\begin{array}{c}6.15 \\
\text { (P1xP3) }\end{array}$ & $\begin{array}{c}2.89 \\
\text { (P1xP5) }\end{array}$ & $\begin{array}{c}5.57 \\
\text { (P5xP4) }\end{array}$ & $\begin{array}{c}2.95 \\
\text { (P4xP5) }\end{array}$ & $\begin{array}{c}5.61 \\
(\mathrm{P} 2 \times \mathrm{P} 1)\end{array}$ \\
\hline FD & $\begin{array}{l}3.27 \\
(\mathrm{P} 2)\end{array}$ & $\begin{array}{l}7.29 \\
(\mathrm{P} 4)\end{array}$ & $\begin{array}{l}3.03 \\
(\mathrm{P} 2)\end{array}$ & $\begin{array}{l}6.61 \\
(\mathrm{P} 4)\end{array}$ & $\begin{array}{l}3.15 \\
(\mathrm{P} 2)\end{array}$ & $\begin{array}{l}6.95 \\
\text { (P4) }\end{array}$ & $\begin{array}{c}3.40 \\
\text { (P4xP5) }\end{array}$ & $\begin{array}{c}6.75 \\
\text { (P3xP5) }\end{array}$ & $\begin{array}{c}3.22 \\
\text { (P4xP5) }\end{array}$ & $\begin{array}{c}6.68 \\
\text { (P5xP4) }\end{array}$ & $\begin{array}{c}3.31 \\
\text { (P4xP5) }\end{array}$ & $\begin{array}{c}6.45 \\
(\mathrm{P} 2 \times \mathrm{P} 1)\end{array}$ \\
\hline SI & $\begin{array}{l}0.78 \\
(\mathrm{P} 2)\end{array}$ & $\begin{array}{l}1.23 \\
\text { (P3) }\end{array}$ & $\begin{array}{l}0.71 \\
(\mathrm{P} 2)\end{array}$ & $\begin{array}{l}1.10 \\
\text { (P3) }\end{array}$ & $\begin{array}{l}0.74 \\
(\mathrm{P} 2)\end{array}$ & $\begin{array}{l}1.17 \\
\text { (P3) }\end{array}$ & $\begin{array}{c}0.74 \\
(\mathrm{P} 3 \times \mathrm{x} 1)\end{array}$ & $\begin{array}{c}0.95 \\
(\mathrm{P} 1 \times \mathrm{xP} 3)\end{array}$ & $\begin{array}{c}0.80 \\
(\mathrm{P} 3 \times \mathrm{P} 1)\end{array}$ & $\begin{array}{c}0.93 \\
(\mathrm{P} 4 \times \mathrm{x} 2)\end{array}$ & $\begin{array}{c}0.77 \\
(\mathrm{P} 3 \times \mathrm{x} 1)\end{array}$ & $\begin{array}{c}0.93 \\
\text { (P1xP3) }\end{array}$ \\
\hline Cla & $\begin{array}{l}0.47 \\
(\mathrm{P} 3)\end{array}$ & $\begin{array}{l}0.65 \\
(\mathrm{P} 1)\end{array}$ & $\begin{array}{l}0.42 \\
\text { (P4) }\end{array}$ & $\begin{array}{l}0.65 \\
\text { (P3) }\end{array}$ & $\begin{array}{l}0.49 \\
\text { (P4) }\end{array}$ & $\begin{array}{l}0.63 \\
(\mathrm{P} 1)\end{array}$ & $\begin{array}{c}0.29 \\
(\mathrm{P} 2 \times \mathrm{P} 4)\end{array}$ & $\begin{array}{c}0.83 \\
(\mathrm{P} 4 \times \mathrm{P} 1)\end{array}$ & $\begin{array}{c}0.27 \\
(\mathrm{P} 5 \times \mathrm{x} 4)\end{array}$ & $\begin{array}{c}0.69 \\
\text { (P3xP5) }\end{array}$ & $\begin{array}{c}0.22 \\
(\mathrm{P} 5 \times \mathrm{xP} 2)\end{array}$ & $\begin{array}{c}0.75 \\
(\mathrm{P} 4 \mathrm{xP} 1)\end{array}$ \\
\hline $\mathrm{CLb}$ & $\begin{array}{l}0.23 \\
\text { (P3) }\end{array}$ & $\begin{array}{l}0.34 \\
(\mathrm{P} 4)\end{array}$ & $\begin{array}{l}0.14 \\
\text { (P3) }\end{array}$ & $\begin{array}{l}0.37 \\
(\mathrm{P} 4)\end{array}$ & $\begin{array}{l}0.19 \\
\text { (P3) }\end{array}$ & $\begin{array}{l}0.36 \\
\text { (P4) }\end{array}$ & $\begin{array}{c}0.16 \\
(\mathrm{P} 5 \times \mathrm{x} 2)\end{array}$ & $\begin{array}{c}0.40 \\
(\mathrm{P} 1 \times \mathrm{xP} 3)\end{array}$ & $\begin{array}{c}0.12 \\
(\mathrm{P} 5 \times \mathrm{P} 1)\end{array}$ & $\begin{array}{c}0.38 \\
(\mathrm{P} 2 \times \mathrm{P} 3)\end{array}$ & $\begin{array}{c}0.15 \\
\text { (P5xP1) }\end{array}$ & $\begin{array}{c}0.39 \\
(\mathrm{P} 2 \times \mathrm{P} 3)\end{array}$ \\
\hline CLt & $\begin{array}{l}0.71 \\
\text { (P3) }\end{array}$ & $\begin{array}{l}1.04 \\
(\mathrm{P} 2)\end{array}$ & $\begin{array}{l}0.79 \\
\text { (P3) }\end{array}$ & $\begin{array}{l}0.98 \\
\text { (P5) }\end{array}$ & $\begin{array}{l}0.75 \\
\text { (P3) }\end{array}$ & $\begin{array}{l}0.96 \\
(\mathrm{P} 2)\end{array}$ & $\begin{array}{c}0.38 \\
(\mathrm{P} 5 \mathrm{xP} 2)\end{array}$ & $\begin{array}{c}1.22 \\
(\mathrm{P} 4 \mathrm{xP} 1)\end{array}$ & $\begin{array}{c}0.40 \\
(\mathrm{P} 5 \times \mathrm{xP} 2)\end{array}$ & $\begin{array}{c}1.00 \\
\text { (P3xP5) }\end{array}$ & $\begin{array}{c}0.39 \\
(\mathrm{P} 5 \times \mathrm{x} 2)\end{array}$ & $\begin{array}{c}1.11 \\
(\mathrm{P} 4 \times \mathrm{PP} 1)\end{array}$ \\
\hline Caro. & $\begin{array}{l}0.22 \\
(\mathrm{P} 1)\end{array}$ & $\begin{array}{l}2.88 \\
(\mathrm{P} 4)\end{array}$ & $\begin{array}{l}0.20 \\
\text { (P5) }\end{array}$ & $\begin{array}{l}2.47 \\
\text { (P4) }\end{array}$ & $\begin{array}{l}0.21 \\
\text { (P5) }\end{array}$ & $\begin{array}{l}2.67 \\
\text { (P4) }\end{array}$ & $\begin{array}{c}0.11 \\
(\mathrm{P} 5 \times \mathrm{x} 4)\end{array}$ & $\begin{array}{c}0.67 \\
(\mathrm{P} 1 \times \mathrm{P} 5)\end{array}$ & $\begin{array}{c}0.14 \\
(\mathrm{P} 5 \times \mathrm{x} 4)\end{array}$ & $\begin{array}{c}0.64 \\
(\mathrm{P} 1 \times \mathrm{P} 5)\end{array}$ & $\begin{array}{c}0.13 \\
\text { (P5xP4) }\end{array}$ & $\begin{array}{c}0.65 \\
\text { (P1xP5) }\end{array}$ \\
\hline T.S.S & $\begin{array}{l}4.86 \\
\text { (P1) }\end{array}$ & $\begin{array}{l}6.43 \\
(\mathrm{P} 2)\end{array}$ & $\begin{array}{l}4.76 \\
(\mathrm{P} 1)\end{array}$ & $\begin{array}{l}6.36 \\
(\mathrm{P} 2)\end{array}$ & $\begin{array}{l}4.81 \\
(\mathrm{P} 1)\end{array}$ & $\begin{array}{l}6.4 \\
(\mathrm{P} 2)\end{array}$ & $\begin{array}{c}4.69 \\
\text { (P1xP3) }\end{array}$ & $\begin{array}{c}6.73 \\
\text { (P5xP4) }\end{array}$ & $\begin{array}{c}4.93 \\
\text { (P1xP3) }\end{array}$ & $\begin{array}{c}6.90 \\
\text { (P5xP4) }\end{array}$ & $\begin{array}{c}4.95 \\
\text { (P1xP3) }\end{array}$ & $\begin{array}{c}6.81 \\
\text { (P5xP4) }\end{array}$ \\
\hline V.C. & $\begin{array}{l}1.352 \\
(\mathrm{P} 5)\end{array}$ & $\begin{array}{l}1.56 \\
(\mathrm{P} 2)\end{array}$ & $\begin{array}{l}1.23 \\
\text { (P3) }\end{array}$ & $\begin{array}{l}1.50 \\
(\mathrm{P} 2)\end{array}$ & $\begin{array}{l}1.29 \\
\text { (P3) }\end{array}$ & $\begin{array}{l}1.53 \\
(\mathrm{P} 2)\end{array}$ & $\begin{array}{c}1.31 \\
(\mathrm{P} 2 \times \mathrm{P} 1)\end{array}$ & $\begin{array}{c}1.47 \\
(\mathrm{P} 3 \times \mathrm{x} 2)\end{array}$ & $\begin{array}{c}1.25 \\
(\mathrm{P} 5 \times \mathrm{P} 1)\end{array}$ & $\begin{array}{c}1.43 \\
(\mathrm{P} 3 \times \mathrm{x} 2)\end{array}$ & $\begin{array}{c}1.30 \\
\text { (P3xP5) }\end{array}$ & $\begin{array}{c}1.45 \\
(\mathrm{P} 3 \times \mathrm{x} 2)\end{array}$ \\
\hline Lyco. & $\begin{array}{c}95.57 \\
(\mathrm{P} 2)\end{array}$ & $\begin{array}{c}111.48 \\
(\mathrm{P} 5)\end{array}$ & $\begin{array}{c}92.13 \\
(\mathrm{P} 1)\end{array}$ & $\begin{array}{c}112.03 \\
(\mathrm{P} 4)\end{array}$ & $\begin{array}{c}94.47 \\
(\mathrm{P} 2)\end{array}$ & $\begin{array}{c}109.87 \\
(\mathrm{P} 4)\end{array}$ & $\begin{array}{c}84.85 \\
(\mathrm{P} 5 \mathrm{xP} 2)\end{array}$ & $\begin{array}{c}114.19 \\
\text { (P4xP5) }\end{array}$ & $\begin{array}{c}82.7 \\
(\mathrm{P} 5 \times \mathrm{x} 2)\end{array}$ & $\begin{array}{c}106.41 \\
\text { (P1xP3) }\end{array}$ & $\begin{array}{c}83.77 \\
(\mathrm{P} 5 \times \mathrm{xP} 2)\end{array}$ & $\begin{array}{c}109.72 \\
\text { (P1xP3) }\end{array}$ \\
\hline
\end{tabular}


Abd El-Aziz, M. H. et al.

Table 7: Range of the specific heterosis relative to the med $\left(\mathrm{H}_{\mathrm{MP}} \%\right)$ and better parent $\left(\mathrm{H}_{\mathrm{MP}} \%\right)$ values (above) of all obtained hybrids (below) for all studied traits

\begin{tabular}{|c|c|c|c|c|c|c|c|c|c|c|c|c|}
\hline \multirow{3}{*}{ Trait } & \multicolumn{6}{|c|}{$\underset{\mathbf{H}_{\mathrm{MP}}}{\mathbf{H}_{\mathrm{Nd}}} \%$} & \multicolumn{6}{|c|}{$\mathrm{H}_{\mathrm{BP}} \%$} \\
\hline & & & & & & & & & & & & \\
\hline & Low. & Hig. & Low. & Hig. & Low. & Hig. & Low. & Hig. & Low. & Hig. & Low. & Hig. \\
\hline $\mathrm{PH}$ & $\begin{array}{c}-22.08 \\
(\mathrm{P} 2 \times \mathrm{P} 3)\end{array}$ & $\begin{array}{c}67.74 \\
(\mathrm{P} 1 x P 4)\end{array}$ & $\begin{array}{c}-20.08 \\
(\mathrm{P} 5 \mathrm{xP} 4)\end{array}$ & $\begin{array}{c}55.04 \\
(\mathrm{P} 1 \mathrm{xP} 4)\end{array}$ & $\begin{array}{c}-20.64 \\
(\mathrm{P} 2 \times \mathrm{P} 3)\end{array}$ & $\begin{array}{c}61.26 \\
(\mathrm{P} 1 \mathrm{xP} 4)\end{array}$ & $\begin{array}{c}-33.75 \\
(\mathrm{P} 2 \times \mathrm{P} 3)\end{array}$ & $\begin{array}{c}64.21 \\
(\mathrm{P} 1 \mathrm{xP} 4)\end{array}$ & $\begin{array}{c}-33.45 \\
(\mathrm{P} 5 \times \mathrm{x} 4)\end{array}$ & $\begin{array}{c}54.64 \\
(\mathrm{P} 1 \mathrm{xP} 4)\end{array}$ & $\begin{array}{c}-31.97 \\
(\mathrm{P} 5 \mathrm{xP} 4)\end{array}$ & $\begin{array}{c}59.79 \\
(\mathrm{P} 1 \times \mathrm{xP} 3)\end{array}$ \\
\hline N.P.B & $\begin{array}{c}-17.29 \\
(\text { P5xP4) }\end{array}$ & $\begin{array}{c}29.52 \\
\text { (P1xP3) }\end{array}$ & $\begin{array}{c}-19.15 \\
\text { (P5xP4) }\end{array}$ & $\begin{array}{c}35.24 \\
\text { (P1xP3) }\end{array}$ & $\begin{array}{c}-18.25 \\
(\mathrm{P} 5 \times \mathrm{xP} 4)\end{array}$ & $\begin{array}{c}32.38 \\
(\mathrm{P} 1 \times \mathrm{xP} 3)\end{array}$ & $\begin{array}{c}-22.22 \\
\text { (P2xP3) }\end{array}$ & $\begin{array}{c}28.30 \\
\text { (P1xP3) }\end{array}$ & $\begin{array}{c}-20.83 \\
\text { (P5xP4) }\end{array}$ & $\begin{array}{c}31.48 \\
\text { (P1xP3) }\end{array}$ & $\begin{array}{c}-20.00 \\
\text { (P5xP4) }\end{array}$ & $\begin{array}{c}31.13 \\
\text { (P1xP3) }\end{array}$ \\
\hline L.A & $\begin{array}{c}-40.61 \\
(\mathrm{P} 4 \times \mathrm{xP} 3)\end{array}$ & $\begin{array}{c}87.71 \\
(\mathrm{P} 5 \mathrm{xP} 2)\end{array}$ & $\begin{array}{c}-29.63 \\
(\mathrm{P} 2 \times \mathrm{x} 4)\end{array}$ & $\begin{array}{c}84.45 \\
\text { (P2xP5) }\end{array}$ & $\begin{array}{c}-33.13 \\
(\mathrm{P} 3 \times \mathrm{x} 4)\end{array}$ & $\begin{array}{c}86.02 \\
\text { (P2xP5) }\end{array}$ & $\begin{array}{c}-50.16 \\
\text { (P5xP4) }\end{array}$ & $\begin{array}{c}59.77 \\
\text { (P2xP5) }\end{array}$ & $\begin{array}{c}-45.71 \\
(\mathrm{P} 2 \times \mathrm{x} 4)\end{array}$ & $\begin{array}{c}83.89 \\
\text { (P2xP5) }\end{array}$ & $\begin{array}{c}-47.49 \\
\text { (P5xP4) }\end{array}$ & $\begin{array}{c}71.29 \\
\text { (P2xP5) }\end{array}$ \\
\hline D.F.F & $\begin{array}{c}25.26 \\
(\mathrm{P} 3 \times \mathrm{P} 1)\end{array}$ & $\begin{array}{c}-14.17 \\
\text { (P1xP4) }\end{array}$ & $\begin{array}{c}8.91 \\
(\mathrm{P} 4 \times \mathrm{xP} 2)\end{array}$ & $\begin{array}{c}-4.30 \\
(\mathrm{P} 1 \mathrm{xP} 3)\end{array}$ & $\begin{array}{c}9.38 \\
(\mathrm{P} 3 \times \mathrm{P} 1)\end{array}$ & $\begin{array}{c}-5.59 \\
(\mathrm{P} 1 \times \mathrm{P} 4)\end{array}$ & $\begin{array}{c}41.22 \\
(\mathrm{P} 3 \mathrm{xP} 4)\end{array}$ & $\begin{array}{c}-5.78 \\
\text { (P2xP5) }\end{array}$ & $\begin{array}{c}13.75 \\
(\mathrm{P} 3 \times \mathrm{x} 4)\end{array}$ & $\begin{array}{c}-3.90 \\
\text { (P1xP5) }\end{array}$ & $\begin{array}{c}15.10 \\
\text { (P3xP4) }\end{array}$ & $\begin{array}{c}-2.34 \\
(\mathrm{P} 1 \times \mathrm{xP} 4)\end{array}$ \\
\hline N.N.F.F.B & $\begin{array}{c}100.00 \\
\text { (P5xP3) }\end{array}$ & $\begin{array}{c}-23.08 \\
(\mathrm{P} 1 \mathrm{xP} 2)\end{array}$ & $\begin{array}{c}45.45 \\
(\mathrm{P} 2 \times \mathrm{P} 4)\end{array}$ & $\begin{array}{c}-33.33 \\
\text { (P3xP5) }\end{array}$ & $\begin{array}{c}56.53 \\
(\mathrm{P} 4 \times \mathrm{xP} 3)\end{array}$ & $\begin{array}{c}-20.00 \\
(\mathrm{P} 1 \times \mathrm{xP} 2)\end{array}$ & $\begin{array}{c}200.00 \\
\text { (P5xP3) }\end{array}$ & $\begin{array}{c}-16.67 \\
(\mathrm{P} 1 \mathrm{xP} 2)\end{array}$ & $\begin{array}{c}80.00 \\
(\mathrm{P} 4 \times \mathrm{xP} 3)\end{array}$ & $\begin{array}{c}-28.57 \\
\text { (P3xP5) }\end{array}$ & $\begin{array}{c}63.64 \\
(\mathrm{P} 4 \times \mathrm{xP} 3)\end{array}$ & $\begin{array}{c}-16.67 \\
(\mathrm{P} 1 \times \mathrm{xP} 2)\end{array}$ \\
\hline NF3P & $\begin{array}{c}-76.58 \\
(\mathrm{P} 4 \times \mathrm{P} 2)\end{array}$ & $\begin{array}{c}522.04 \\
\text { (P1xP4) }\end{array}$ & $\begin{array}{c}-67.16 \\
(\mathrm{P} 4 \times \mathrm{P} 2)\end{array}$ & $\begin{array}{c}241.91 \\
\text { (P1xP5) }\end{array}$ & $\begin{array}{c}-71.80 \\
(\mathrm{P} 4 \mathrm{xP} 2)\end{array}$ & $\begin{array}{c}406.58 \\
\text { (P1xP4) }\end{array}$ & $\begin{array}{c}-87.83 \\
(\mathrm{P} 4 \times \mathrm{P} 2)\end{array}$ & $\begin{array}{c}243.36 \\
\text { (P1xP4) }\end{array}$ & $\begin{array}{c}-78.23 \\
(\mathrm{P} 4 \times \mathrm{P} 2)\end{array}$ & $\begin{array}{c}307.65 \\
\text { (P1xP4) }\end{array}$ & $\begin{array}{c}-83.54 \\
(\mathrm{P} 4 \mathrm{xP} 2)\end{array}$ & $\begin{array}{c}270.35 \\
(\mathrm{P} 1 \times \mathrm{P} 4)\end{array}$ \\
\hline WF3P & $\begin{array}{c}-68.71 \\
(\mathrm{P} 5 \times \mathrm{xP} 1)\end{array}$ & $\begin{array}{c}208.63 \\
\text { (P2xP3) }\end{array}$ & $\begin{array}{c}-75.06 \\
(\mathrm{P} 5 \mathrm{xP} 4)\end{array}$ & $\begin{array}{c}497.26 \\
\text { (P2xP3) }\end{array}$ & $\begin{array}{c}-69.16 \\
(\mathrm{P} 5 \times \mathrm{P} 1)\end{array}$ & $\begin{array}{c}301.05 \\
(\mathrm{P} 2 \mathrm{xP} 3)\end{array}$ & $\begin{array}{c}-69.91 \\
(\mathrm{P} 5 \mathrm{xP} 1)\end{array}$ & $\begin{array}{c}125.51 \\
\text { (P2xP3) }\end{array}$ & $\begin{array}{c}-86.01 \\
(\mathrm{P} 3 \times \mathrm{xP} 4)\end{array}$ & $\begin{array}{c}484.97 \\
(\mathrm{P} 2 \times \mathrm{x} 3)\end{array}$ & $\begin{array}{c}-67.49 \\
(\mathrm{P} 3 \times \mathrm{P} 4)\end{array}$ & $\begin{array}{c}222.76 \\
\text { (P2xP3) }\end{array}$ \\
\hline TNF & $\begin{array}{c}-70.09 \\
(\mathrm{P} 5 \times \mathrm{x} 3)\end{array}$ & $\begin{array}{c}671.58 \\
\text { (P1xP4) }\end{array}$ & $\begin{array}{c}-65.64 \\
\text { (P5xP3) }\end{array}$ & $\begin{array}{c}626.75 \\
\text { (P1xP4) }\end{array}$ & $\begin{array}{c}-67.94 \\
\text { (P5xP3) }\end{array}$ & $\begin{array}{c}648.67 \\
\text { (P1xP4) }\end{array}$ & $\begin{array}{c}-81.42 \\
(\mathrm{P} 4 \mathrm{xP} 3)\end{array}$ & $\begin{array}{c}498.33 \\
\text { (P1xP4) }\end{array}$ & $\begin{array}{c}-78.24 \\
(\mathrm{P} 4 x \mathrm{xP})\end{array}$ & $\begin{array}{c}530.08 \\
(\mathrm{P} 1 \mathrm{xP} 4)\end{array}$ & $\begin{array}{c}-79.91 \\
(\mathrm{P} 4 \times \mathrm{xP} 3)\end{array}$ & $\begin{array}{c}637.77 \\
\text { (P1xP5) }\end{array}$ \\
\hline TWF & $\begin{array}{c}-55.94 \\
(\mathrm{P} 5 \times \mathrm{P} 3)\end{array}$ & $\begin{array}{c}123.74 \\
\text { (P2xP5) }\end{array}$ & $\begin{array}{c}-59.07 \\
(\mathrm{P} 5 \mathrm{xP} 4)\end{array}$ & $\begin{array}{c}148.19 \\
\text { (P2xP5) }\end{array}$ & $\begin{array}{c}-55.16 \\
\text { (P5xP4) }\end{array}$ & $\begin{array}{c}114.84 \\
(\mathrm{P} 1 \times P 2)\end{array}$ & $\begin{array}{c}-49.40 \\
\text { (P4xP5) }\end{array}$ & $\begin{array}{c}50.41 \\
(\mathrm{P} 1 \mathrm{xP} 2)\end{array}$ & $\begin{array}{c}-63.76 \\
\text { (P4xP5) }\end{array}$ & $\begin{array}{c}76.15 \\
\text { (P2xP5) }\end{array}$ & $\begin{array}{c}-60.02 \\
\text { (P5xP4) }\end{array}$ & $\begin{array}{c}62.11 \\
(\mathrm{P} 1 \times \mathrm{xP} 2)\end{array}$ \\
\hline N.L.F & $\begin{array}{c}-42.86 \\
(\mathrm{P} 5 \mathrm{xP} 2)\end{array}$ & $\begin{array}{c}88.89 \\
(\mathrm{P} 3 \times \mathrm{P} 1)\end{array}$ & $\begin{array}{c}-40.00 \\
(\mathrm{P} 4 \mathrm{xP5})\end{array}$ & $\begin{array}{c}77.78 \\
(\mathrm{P} 3 \mathrm{xP} 1)\end{array}$ & $\begin{array}{c}-40.35 \\
(\mathrm{P} 5 \times \mathrm{P} 2)\end{array}$ & $\begin{array}{c}83.33 \\
(\mathrm{P} 3 \mathrm{xP} 1)\end{array}$ & $\begin{array}{c}-46.67 \\
(\mathrm{P} 5 \mathrm{xP} 2)\end{array}$ & $\begin{array}{c}41.67 \\
(\mathrm{P} 3 \mathrm{xP} 1)\end{array}$ & $\begin{array}{c}-40.00 \\
(\mathrm{P} 3 \times \mathrm{PP} 4)\end{array}$ & $\begin{array}{c}33.33 \\
(\mathrm{P} 3 \mathrm{xP} 1)\end{array}$ & $\begin{array}{c}-43.33 \\
(\mathrm{P} 5 \mathrm{xP} 2)\end{array}$ & $\begin{array}{c}37.50 \\
(\mathrm{P} 3 \times \mathrm{P} 1)\end{array}$ \\
\hline F.F & $\begin{array}{c}-59.06 \\
\text { (P1xP5) }\end{array}$ & $\begin{array}{c}46.11 \\
(\mathrm{P} 2 \times \mathrm{P} 1)\end{array}$ & $\begin{array}{c}-56.00 \\
(\mathrm{P} 3 \times \mathrm{P} 1)\end{array}$ & $\begin{array}{c}36.00 \\
(\mathrm{P} 2 \times \mathrm{P} 1)\end{array}$ & $\begin{array}{c}-59.03 \\
(\mathrm{P} 4 \times \mathrm{xP} 5)\end{array}$ & $\begin{array}{c}40.94 \\
(\mathrm{P} 2 \times \mathrm{P} 1)\end{array}$ & $\begin{array}{c}-67.74 \\
\text { (P4xP5) }\end{array}$ & $\begin{array}{c}7.94 \\
\text { (P3xP4) }\end{array}$ & $\begin{array}{c}-56.69 \\
(\mathrm{P} 3 \times \mathrm{P} 1)\end{array}$ & $\begin{array}{c}2.36 \\
\text { (P3xP5) }\end{array}$ & $\begin{array}{c}-59.18 \\
(\mathrm{P} 2 \times \mathrm{x} 4)\end{array}$ & $\begin{array}{c}5.12 \\
(\mathrm{P} 3 \times \mathrm{P} 5)\end{array}$ \\
\hline P.T & $\begin{array}{c}-30.67 \\
(\mathrm{P} 1 \times \mathrm{P} 4)\end{array}$ & $\begin{array}{c}62.46 \\
(\mathrm{P} 2 \mathrm{xP} 3)\end{array}$ & $\begin{array}{c}-26.26 \\
\text { (P1xP5) }\end{array}$ & $\begin{array}{c}51.26 \\
\text { (P2xP5) }\end{array}$ & $\begin{array}{c}-27.08 \\
\text { (P1xP5) }\end{array}$ & $\begin{array}{c}56.16 \\
(\mathrm{P} 2 \times \mathrm{x} 3)\end{array}$ & $\begin{array}{c}-42.38 \\
(\mathrm{P} 5 \mathrm{xP} 2)\end{array}$ & $\begin{array}{c}15.99 \\
(\mathrm{P} 2 \mathrm{xP} 3)\end{array}$ & $\begin{array}{c}-32.33 \\
(\mathrm{P} 2 \times \mathrm{P} 4)\end{array}$ & $\begin{array}{c}16.71 \\
\text { (P3xP5) }\end{array}$ & $\begin{array}{c}-35.82 \\
(\mathrm{P} 2 \mathrm{xP} 4)\end{array}$ & $\begin{array}{c}15.31 \\
\text { (P3xP5) }\end{array}$ \\
\hline FL & $\begin{array}{c}-46.61 \\
(\mathrm{P} 4 x \mathrm{x} 5)\end{array}$ & $\begin{array}{c}30.14 \\
(\mathrm{P} 2 \times \mathrm{P} 1)\end{array}$ & $\begin{array}{c}-45.12 \\
\text { (P4xP5) }\end{array}$ & $\begin{array}{c}57.00 \\
(\mathrm{P} 2 \times \mathrm{P} 1)\end{array}$ & $\begin{array}{c}-45.55 \\
(\mathrm{P} 4 \times \mathrm{xP} 5)\end{array}$ & $\begin{array}{c}42.21 \\
(\mathrm{P} 2 \mathrm{xP} 1)\end{array}$ & $\begin{array}{c}-41.19 \\
(\mathrm{P} 1 \mathrm{xP} 4)\end{array}$ & $\begin{array}{c}19.79 \\
\text { (P1xP3) }\end{array}$ & $\begin{array}{c}-45.96 \\
(\mathrm{P} 4 x P 5)\end{array}$ & $\begin{array}{c}13.51 \\
(\mathrm{P} 2 \times \mathrm{P} 1)\end{array}$ & $\begin{array}{c}-48.02 \\
(\mathrm{P} 4 \times \mathrm{x} 5)\end{array}$ & $\begin{array}{c}14.30 \\
(\mathrm{P} 1 \mathrm{xP} 3)\end{array}$ \\
\hline FD & $\begin{array}{c}-47.31 \\
(\mathrm{P} 4 \times \mathrm{xP5})\end{array}$ & $\begin{array}{c}42.16 \\
(\mathrm{P} 2 \times \mathrm{P} 1)\end{array}$ & $\begin{array}{c}-47.36 \\
\text { (P4xP5) }\end{array}$ & $\begin{array}{c}44.40 \\
(\mathrm{P} 2 \times \mathrm{P} 1)\end{array}$ & $\begin{array}{c}-47.33 \\
(\mathrm{P} 4 \times \mathrm{x} 5)\end{array}$ & $\begin{array}{c}43.25 \\
(\mathrm{P} 2 \mathrm{xP} 1)\end{array}$ & $\begin{array}{c}-53.31 \\
\text { (P4xP5) }\end{array}$ & $\begin{array}{c}26.90 \\
(\mathrm{P} 2 \times \mathrm{P} 3)\end{array}$ & $\begin{array}{c}-42.28 \\
(\mathrm{P} 1 \times \mathrm{xP})\end{array}$ & $\begin{array}{c}10.43 \\
\text { (P4xP5) }\end{array}$ & $\begin{array}{c}-40.38 \\
(\mathrm{P} 1 \mathrm{xP} 4)\end{array}$ & $\begin{array}{c}11.64 \\
(\mathrm{P} 3 \times \mathrm{x} 5)\end{array}$ \\
\hline SI & $\begin{array}{c}-28.55 \\
(\mathrm{P} 3 \times \mathrm{P} 1)\end{array}$ & $\begin{array}{c}6.72 \\
(\mathrm{P} 4 \times \mathrm{P} 2)\end{array}$ & $\begin{array}{c}-18.64 \\
(\mathrm{P} 3 \times \mathrm{P} 1)\end{array}$ & $\begin{array}{c}21.91 \\
(\mathrm{P} 4 \mathrm{xP} 2)\end{array}$ & $\begin{array}{c}-23.75 \\
(\mathrm{P} 3 \times \mathrm{P} 1)\end{array}$ & $\begin{array}{c}14.20 \\
(\mathrm{P} 4 \mathrm{xP} 2)\end{array}$ & $\begin{array}{c}-39.62 \\
(\mathrm{P} 3 \times \mathrm{P} 1)\end{array}$ & $\begin{array}{c}4.96 \\
(\mathrm{P} 4 \mathrm{xP} 2)\end{array}$ & $\begin{array}{c}-27.49 \\
(\mathrm{P} 3 \times \mathrm{P} 1)\end{array}$ & $\begin{array}{c}14.23 \\
(\mathrm{P} 4 \mathrm{xP} 2)\end{array}$ & $\begin{array}{c}-33.91 \\
(\mathrm{P} 3 \times \mathrm{P} 1)\end{array}$ & $\begin{array}{c}9.64 \\
(\mathrm{P} 4 \times \mathrm{xP} 2)\end{array}$ \\
\hline $\mathrm{Cla}$ & $\begin{array}{c}-64.07 \\
\text { (P5xP2) }\end{array}$ & $\begin{array}{c}36.64 \\
(\mathrm{P} 4 \times \mathrm{P} 1)\end{array}$ & $\begin{array}{c}-62.01 \\
(\mathrm{P} 5 \mathrm{xP} 2)\end{array}$ & $\begin{array}{c}26.82 \\
(\mathrm{P} 1 \mathrm{xP} 4)\end{array}$ & $\begin{array}{c}-52.25 \\
(\mathrm{P} 3 \times \mathrm{P} 2)\end{array}$ & $\begin{array}{c}34.17 \\
(\mathrm{P} 4 \times \mathrm{xP} 1)\end{array}$ & $\begin{array}{c}-64.34 \\
(\mathrm{P} 5 \mathrm{xP} 2)\end{array}$ & $\begin{array}{c}26.16 \\
(\mathrm{P} 4 \times \mathrm{P} 1)\end{array}$ & $\begin{array}{c}-62.99 \\
(\mathrm{P} 5 \times \mathrm{x} 2)\end{array}$ & $\begin{array}{c}12.33 \\
(\mathrm{P} 1 x \mathrm{P} 3)\end{array}$ & $\begin{array}{c}-63.39 \\
(\mathrm{P} 5 \mathrm{xP} 2)\end{array}$ & $\begin{array}{c}53.19 \\
(\mathrm{P} 4 \times \mathrm{xP} 1)\end{array}$ \\
\hline CLb & $\begin{array}{c}-44.08 \\
(\mathrm{P} 5 \times \mathrm{x} 2)\end{array}$ & $\begin{array}{c}43.15 \\
(\mathrm{P} 2 \times \mathrm{P} 3)\end{array}$ & $\begin{array}{c}-64.79 \\
(\mathrm{P} 5 \mathrm{xP} 1)\end{array}$ & $\begin{array}{c}83.18 \\
(\mathrm{P} 2 \times \mathrm{P} 3)\end{array}$ & $\begin{array}{c}-52.11 \\
(\mathrm{P} 5 \times \mathrm{x} 1)\end{array}$ & $\begin{array}{c}60.36 \\
(\mathrm{P} 2 \mathrm{xP} 3)\end{array}$ & $\begin{array}{c}-47.83 \\
(\mathrm{P} 5 \mathrm{xP} 2)\end{array}$ & $\begin{array}{c}25.67 \\
(\mathrm{P} 2 \times \mathrm{P} 3)\end{array}$ & $\begin{array}{c}-66.16 \\
(\mathrm{P} 5 \mathrm{xP} 1)\end{array}$ & $\begin{array}{c}38.04 \\
(\mathrm{P} 2 \times \mathrm{x} 3)\end{array}$ & $\begin{array}{c}-53.42 \\
(\mathrm{P} 5 \mathrm{xP} 1)\end{array}$ & $\begin{array}{c}31.94 \\
(\mathrm{P} 2 \times \mathrm{xP} 3)\end{array}$ \\
\hline CLt & $\begin{array}{c}-60.08 \\
(\mathrm{P} 5 \times \mathrm{P} 2)\end{array}$ & $\begin{array}{c}29.22 \\
(\mathrm{P} 4 \mathrm{xP} 1)\end{array}$ & $\begin{array}{c}-57.11 \\
(\mathrm{P} 5 \mathrm{xP} 2)\end{array}$ & $\begin{array}{c}15.67 \\
\text { (P1xP3) }\end{array}$ & $\begin{array}{c}-58.93 \\
(\mathrm{P} 5 \times \mathrm{P} 2)\end{array}$ & $\begin{array}{c}22.09 \\
(\mathrm{P} 4 \mathrm{xP} 1)\end{array}$ & $\begin{array}{c}-63.73 \\
(\mathrm{P} 5 \mathrm{xP} 2)\end{array}$ & $\begin{array}{c}23.36 \\
(\mathrm{P} 4 \mathrm{xP} 1)\end{array}$ & $\begin{array}{c}-59.31 \\
(\mathrm{P} 5 \times \mathrm{P} 2)\end{array}$ & $\begin{array}{c}7.10 \\
\text { (P1xP3) }\end{array}$ & $\begin{array}{c}-59.58 \\
(\mathrm{P} 5 \mathrm{xP} 2)\end{array}$ & $\begin{array}{c}15.13 \\
(\mathrm{P} 4 \times \mathrm{P} 1)\end{array}$ \\
\hline Caro. & $\begin{array}{c}-92.47 \\
(\mathrm{P} 5 \times \mathrm{xP} 4)\end{array}$ & $\begin{array}{c}195.71 \\
\text { (P1xP5) }\end{array}$ & $\begin{array}{c}-89.04 \\
(\mathrm{P} 5 \mathrm{xP} 4)\end{array}$ & $\begin{array}{c}186.87 \\
\text { (P1xP5) }\end{array}$ & $\begin{array}{c}-90.89 \\
(\mathrm{P} 5 \times \mathrm{x} 4)\end{array}$ & $\begin{array}{c}191.33 \\
\text { (P1xP5) }\end{array}$ & $\begin{array}{c}-95.93 \\
(\mathrm{P} 5 \mathrm{xP} 4)\end{array}$ & $\begin{array}{c}190.01 \\
\text { (P1xP5) }\end{array}$ & $\begin{array}{c}-94.09 \\
(\mathrm{P} 5 \times \mathrm{xP} 4)\end{array}$ & $\begin{array}{c}164.01 \\
\text { (P1xP5) }\end{array}$ & $\begin{array}{c}-95.07 \\
(\mathrm{P} 5 \mathrm{xP} 2)\end{array}$ & $\begin{array}{c}182.10 \\
\text { (P1xP5) }\end{array}$ \\
\hline T.S.S & $\begin{array}{c}-10.64 \\
(\mathrm{P} 2 \mathrm{xP5})\end{array}$ & $\begin{array}{c}17.93 \\
\text { (P1xP5) }\end{array}$ & $\begin{array}{c}-17.11 \\
(\mathrm{P} 2 \mathrm{xP5})\end{array}$ & $\begin{array}{c}21.47 \\
\text { (P1xP5) }\end{array}$ & $\begin{array}{c}-5.28 \\
(\mathrm{P} 2 \mathrm{xP} 3)\end{array}$ & $\begin{array}{c}19.69 \\
\text { (P1xP5) }\end{array}$ & $\begin{array}{c}-19.17 \\
(\mathrm{P} 2 \mathrm{xP} 1)\end{array}$ & $\begin{array}{c}10.38 \\
(\mathrm{P} 5 \mathrm{xP} 4)\end{array}$ & $\begin{array}{c}-15.30 \\
(\mathrm{P} 2 \mathrm{xP5})\end{array}$ & $\begin{array}{c}11.89 \\
(\mathrm{P} 5 \mathrm{xP} 4)\end{array}$ & $\begin{array}{c}-15.89 \\
(\mathrm{P} 2 \mathrm{xP5})\end{array}$ & $\begin{array}{c}11.75 \\
\text { (P5xP4) }\end{array}$ \\
\hline V.C. & $\begin{array}{c}-10.41 \\
(\mathrm{P} 2 \times \mathrm{P} 1)\end{array}$ & $\begin{array}{c}7.86 \\
\text { (P5xP4) }\end{array}$ & $\begin{array}{c}-12.7 \\
(\mathrm{P} 4 \times \mathrm{P} 2)\end{array}$ & $\begin{array}{c}4.68 \\
(\mathrm{P} 3 \times \mathrm{P} 1)\end{array}$ & $\begin{array}{c}-8.72 \\
(\mathrm{P} 2 \times \mathrm{P} 1)\end{array}$ & $\begin{array}{c}4.60 \\
(\mathrm{P} 5 \times \mathrm{xP} 4)\end{array}$ & $\begin{array}{c}-16.32 \\
(\mathrm{P} 5 \mathrm{xP} 3)\end{array}$ & $\begin{array}{c}7.44 \\
(\mathrm{P} 5 \mathrm{xP} 4)\end{array}$ & $\begin{array}{c}-15.25 \\
(\mathrm{P} 2 \times \mathrm{P} 3)\end{array}$ & $\begin{array}{c}10.61 \\
(\mathrm{P} 3 \times \mathrm{x} 1)\end{array}$ & $\begin{array}{c}-13.88 \\
(\mathrm{P} 2 \mathrm{xP} 1)\end{array}$ & $\begin{array}{c}6.91 \\
\text { (P5xP4) }\end{array}$ \\
\hline Lyco. & $\begin{array}{c}-18.04 \\
(\mathrm{P} 5 \times \mathrm{x} 2)\end{array}$ & $\begin{array}{c}11.26 \\
\text { (P1xP3) }\end{array}$ & $\begin{array}{c}-17.29 \\
(\mathrm{P} 5 \mathrm{xP} 2)\end{array}$ & $\begin{array}{c}9.82 \\
\text { (P1xP3) }\end{array}$ & $\begin{array}{c}-17.67 \\
\text { (P5xP2) }\end{array}$ & $\begin{array}{c}10.56 \\
(\mathrm{P} 1 \times \mathrm{xP} 3)\end{array}$ & $\begin{array}{c}-23.88 \\
(\mathrm{P} 5 \mathrm{xP} 2)\end{array}$ & $\begin{array}{c}6.26 \\
\text { (P1xP3) }\end{array}$ & $\begin{array}{c}-23.93 \\
(\mathrm{P} 4 \times \mathrm{P} 2)\end{array}$ & $\begin{array}{c}5.40 \\
(\mathrm{P} 2 \times \mathrm{P} 1)\end{array}$ & $\begin{array}{c}-23.16 \\
(\mathrm{P} 5 \mathrm{xP} 2)\end{array}$ & $\begin{array}{c}5.48 \\
(\mathrm{P} 1 \times \mathrm{PP} 3)\end{array}$ \\
\hline
\end{tabular}

From UPGMA clustering dendrogram for five Tomato lines based on PD values as shown in Figure 5, it is observed that these lines could be divided into two main groups (A and $\mathrm{B}$ ) with different degrees of PD (ranged from 0.081 to 0.428 with mean 0.236 ). The first group (A) included two subgroups (c) and (d), the first subgroup (c) involved two lines P1 and P5 as well as, the other subgroup (d) included the two lines P2 and P3,

Table (8): Phenotypic distances between five Tomato lines based on values of mean performance for all studied traits in the two seasons and combine them.

\begin{tabular}{cccccc}
\hline & P1 & P2 & P3 & P4 & Season \\
\hline \multirow{3}{*}{ P2 } & 0.214 & & & & S1 \\
& 0.233 & & & & S2 \\
& 0.222 & & & & Comb. \\
\hline \multirow{3}{*}{ P3 } & 0.233 & 0.053 & & & S1 \\
& 0.269 & 0.115 & & & S2 \\
& 0.250 & 0.081 & & & Comb. \\
\hline \multirow{3}{*}{ P4 } & 0.347 & 0.480 & 0.466 & & S1 \\
& 0.213 & 0.438 & 0.418 & & S2 \\
& 0.238 & 0.428 & 0.422 & & Comb. \\
P5 & 0.081 & 0.141 & 0.159 & 0.384 & S1 \\
& 0.105 & 0.141 & 0.206 & 0.288 & S2 \\
& 0.089 & 0.141 & 0.179 & 0.309 & Comb. \\
\hline
\end{tabular}

while the second group (B) is comprised by inbred line P4 only. This indicates that the cluster analysis based on combined data of PD for two different climatic seasons also succeeded in description of phenotypic diversity and heterogeneity within studied lines. Also, indicates the presence of clear variance between all studied lines, this also reflect the agronomic diversity within these lines.

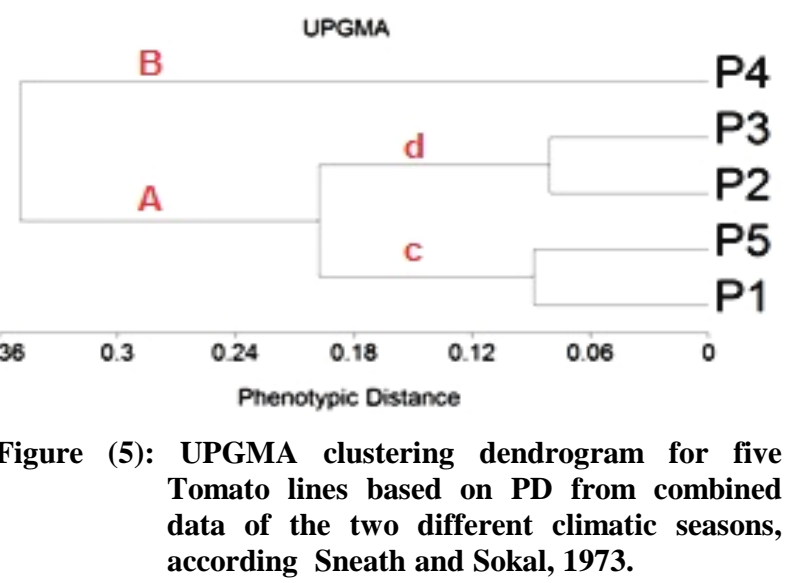


Relationship between MD and PD, as well as their relationships with heterosis

Correlation values presented in Table 9 indicated that the values of MD between parental lines based on data of RAPD, ISSRs and combined data were insignificant negatively correlated with the values of PD between parental lines based on data of mean performance for all studied traits in the two seasons and combined data. Where poor correlation $(r=-0.484)$ was found between MD and PD for the combined data for both types of distances.

Table (9: Correlation relationships among the types of genetic distances (MD and PD)

\begin{tabular}{llllll}
\hline $\begin{array}{l}\text { Genetic } \\
\text { distances }\end{array}$ & MD $_{\text {comb }}$ & MD $_{\text {RAPD }}$ & MD $_{\text {ISSR }}$ & PD $_{\text {comb }}$ & PD $_{\text {S1 }}$ \\
\hline MD $_{\text {RAPD }}$ & $0.957^{* *}$ & & & & \\
MD $_{\text {ISSR }}$ & $0.789^{* *}$ & $0.584^{* *}$ & & & \\
PD $_{\text {comb }}$ & $-0.484^{n s}$ & $-0.458^{n s}$ & $-0.409^{n s}$ & & \\
PD $_{\text {S1 }}$ & $-0.417^{n s}$ & $-0.402^{n s}$ & $-0.312^{\text {ns }}$ & $0.970^{* *}$ & \\
PD $_{\text {S2 }}$ & $-0.530^{n s}$ & $-0.497^{n s}$ & $-0.470^{\text {ns }}$ & $0.988^{* *}$ & $0.924^{* *}$ \\
\hline
\end{tabular}

**Significant value at 0.01 levels probability, ${ }^{\text {ns }}$ insignificant value

In harmony with this result, a poor correlation between molecular and phenotypic distances was found as well (Dillmann et al., 1997; Sant et al., 1999; Yadav et al., 2010 and El-Aziz et al., 2016). While, significant positive correlations were found among the three types of MD, as well as between the three types of PD. This result demonstrates the reliability of molecular and phenotypic assessment, apart from the lack of a significant correlation between them.

Finally, to achieve the last objective for this study, the correlation values ( $\mathrm{r})$ among heterosis $\left(\mathrm{H}_{\mathrm{MP}} \%\right.$, $\mathrm{H}_{\mathrm{BP}} \%$ ) and genetic distances (MD, PD) based on combined data for all studied traits were computed as shown in Table 10.

Table (10): Correlation relationships among heterosis $\left(\mathrm{H}_{\mathrm{MP}} \%, \mathrm{H}_{\mathrm{BP}} \%\right)$ and genetic distances (MD, PD) based on combined data for all studied traits.

\begin{tabular}{|c|c|c|c|c|}
\hline \multirow{2}{*}{ Trait } & \multicolumn{2}{|c|}{ MD } & \multicolumn{2}{|c|}{ PD } \\
\hline & $\mathbf{H}_{\mathrm{MP}} \%$ & $\mathrm{H}_{\mathrm{BP}} \%$ & $\mathrm{H}_{\mathrm{MP}} \%$ & $\mathrm{H}_{\mathrm{BP}} \%$ \\
\hline$\overline{\mathrm{PH}}$ & 0.429 & 0.384 & 0.136 & 0.127 \\
\hline N.P.B & 0.42 & 0.421 & -0.195 & -0.020 \\
\hline L.A & 0.439 & 0.365 & $-0.502 *$ & $-0.442 *$ \\
\hline D.F.F & -0.278 & -0.391 & -0.028 & 0.056 \\
\hline N.N.F.F.B & -0.182 & -0.215 & 0.287 & 0.263 \\
\hline NF3P & 0.363 & 0.398 & -0.165 & -0.248 \\
\hline WF3P & 0.33 & 0.34 & $-0.498^{*}$ & $-0.536^{*}$ \\
\hline TNF & 0.353 & 0.414 & -0.079 & -0.292 \\
\hline TWF & $0.517^{*}$ & $0.437 *$ & -0.394 & -0.414 \\
\hline N.L.F & 0.064 & 0.289 & -0.180 & -0.155 \\
\hline F.F & 0.099 & -0.095 & -0.112 & -0.092 \\
\hline P.T & 0.018 & -0.239 & -0.172 & -0.146 \\
\hline FL & -0.03 & -0.183 & 0.011 & 0.021 \\
\hline FD & -0.055 & -0.007 & -0.150 & -0.365 \\
\hline SI & 0.28 & 0.312 & 0.200 & 0.197 \\
\hline Cla & 0.068 & 0.194 & 0.040 & -0.028 \\
\hline CLb & -0.018 & 0.14 & -0.200 & -0.300 \\
\hline CLt & 0.013 & 0.11 & 0.052 & 0.040 \\
\hline Caro. & 0.272 & 0.302 & $-0.636^{* *}$ & $-0.656 * *$ \\
\hline T.S.S & -0.158 & $-0.486^{*}$ & 0.042 & 0.245 \\
\hline V.C. & -0.211 & -0.177 & 0.049 & -0.050 \\
\hline Lyco. & 0.226 & 0.056 & -0.060 & -0.014 \\
\hline
\end{tabular}

These results showed that poor correlation coefficients among MD with $\mathrm{H}_{\mathrm{MP}} \%$ and $\mathrm{H}_{\mathrm{BP}} \%$ in all studied traits, except with TWF and T.S.S traits. In the same manner, the correlation coefficients among PD with $\mathrm{H}_{\mathrm{MP}} \%$ and $\mathrm{H}_{\mathrm{BP}} \%$ were poor, except with L.A, WF3P and Caro. traits. The poor correlation among two types of genetic distances with $\mathrm{F}_{1}$ heterosis can be explicated by the fact that hybrids obtained from all studied lines had been evaluated at a one location apart from evaluated under different climatic conditions. Since the heterotic response of a gene pool does not depend upon the distance between parents alone, however also on the adaptability to various environments (de Souza et al., 2012).

\section{CONCLUSION AND RECOMMENDATION}

Even though that RAPD technique was better than ISSRs technique in assessment for molecular diversity and discrimination capacity for all studied lines of tomato, however, both techniques were suitable tools for detecting reproducible polymorphic patterns and confirmed to be valid in discriminating studied lines through various specific markers which succeeded in this respect. Moreover, the various traits estimated under two different climatic seasons also succeeded in description of phenotypic diversity and heterogeneity within studied lines. However, insignificant correlations were found among the distances computed based on these two types of genetic diversity as well as, the correlation relationships among these distances and heterosis for most studied traits were not significant.

So through this study we recommend plant breeders to do evaluate genetic diversity for inbred lines which are using as parents in breeding and improvement programs of tomato at more than location or allocation and under different climatic conditions. Also, doing evaluation through a more number of variable molecular markers as well as depending on a more number of phenotypic traits. Hence, achieving the desired goal from this evaluation, which is the prediction of heterosis for all important traits and which will lead to provision of strenuous efforts to assess hybrids in most breeding programs.

\section{REFERENCES}

Abd El-Aziz, M. H. and Rehab M. M. Habiba (2016). Molecular assessment of genetic diversity in some Canola homozygous lines. Egypt. J. Genet. Cytol., 45:129-145.

Abd El-Aziz, M. H.; A. N. Attia;M. S. Sultan; M. A. Badawi; and A. R. M. Al-Rawi (2016). Phenotypic and genetic diversity and their relationship to $F_{1}$ performance for yield traits in some Maize lines. J. Agric. Chem. and Biotechn., Mansoura Univ. 7 (3): 95- 104.

Abd El-Hady, Elham, A. A.; A. A. A. Haiba; R. Abd El-Hamid; Nagwa, M. F. A. Al-Ansary and A. Y. Mohamed (2010). Assessment of genetic variations in some Vigna species by RAPD and ISSR analysis. New York Science J., 3(11): 120-128.

Adhikari, S., S. Saha, T. K. Bandyopadhyay and P. Ghosh (2015). Efficiency of ISSR marker for characterization of Cymbopogon germplasms and their suitability in molecular barcoding. Plant Systematics and Evolution, 301:439-450. 
Babic, M.; V. Babic; S. Prodanovic; M. Filipovic and V. Andjelkovic (2012). Comparison of morphological and molecular genetic distances of maize inbreds. Genetika, 44(1): 119-128.

Beuningen, V. L. T. and R. H. Busch (1997). Genetic diversity among North American spring wheat cultivars: III. Cluster analysis based on quantitative morphological traits. Crop Sci., 37: 981-988.

Chowdhury, M. A.; B. Vandenberg and T. Warkentin (2002). Cultivar identification and genetic relationship among selected breeding lines and cultivars in chickpea (Cicer arietinum L.) . Euphytica, 127: 317-325.

de Souza, S. G. H.; V. Carpentieri-Pípolo; D. D. Garbúglio; N. S. F. Júnior; C. F. Ruas and P. M. Ruas (2012). Genetic Distance Estimated by RAPD Markers and Performance of Topcross Hybrids in Popcorn. American J. of Plant Sciences, 3: 1666-1673.

Dillmann, C.; A. Bar-Hen; D. Guérin; A. Charcosset and A. Murigneux (1997). Comparison of RFLP and morphological distances between maize zea mays lines. Consequences for germplasm protection purposes.Theor. Appl. Genet., 95: 92-102.

Drinic, S. M.; M. Kostadinovic; D. Ristic; M. Stevanovic; Z. Camdžija; M. Filipovic and D. Ovacevic (2012). Correlation of yield and heterosis of maize hybrids and their parental lines with genetic distance based on SSR. Genetika, 44(2): 399-408.

El-Zanaty, A. M.; Mona H. El-Hadary; M. Ismail and A. A. ElGammal (2013). Genetic diversity of wheat genotypes based on RAPD relative to $\mathrm{F}_{1}$ hybrid performance. Inter. J. of Agron. and Plant Production, 4 (5):1098-1107.

Evgenidis, G.; E. T. Mavrona and M. K. Sotiriou (2011). Principal component and cluster analysis as a tool in the assessment of Tomato hybrids and cultivars. International J. Agron. 27: ref.

Fernández, M. E.; A. M. Figueiras and C. Benito (2002). The use of ISSR and RAPD markers for detecting DNA polymorphism, genotype identification and genetic diversity among barley cultivars with known origin. Theor. Appl. Genet., 104: 845-851.

Goulao, L. and C. M. Oliveira (2001). Molecular characterization of cultivars of apple (Malus $\times$ domestica Borkh.) using microsatellite (SSR and ISSR) markers. Euphytica, 122: 81-89.

Gupta, P. K.; Varshney, R. K.; Sharma, P. C. and B. Ramesh (1999). Molecular markers and their applications in wheat breeding. Plant Breed., 118: 369-390.

Hasnaoui, N., M. Mars, J. Chibani and M. Trifi (2010). Molecular polymorphisms in Tunisian Pomegranate (Punica granatum $\mathrm{L}$.) as revealed by RAPD fingerprints. Diversity, 2: $107-114$.

Hassan, Neveen, A.; Mostafa, Shimaa and A. Twfik (2013). Assessment of genetic diversity of Tomato (lycopersicon esculentum L.) germplasm using molecular markers (RAPD and ISSR). Egypt. J. Genet. Cytol., 42:163-182.

Henareh, M.; A. Dursun and B. A. Mandoulakani (2015). Genetic diversity in tomato landraces collected from Turkey and Iran revealed by morphological characters. Acta Sci. Pol. Hortorum Cultus, 14(2): 87-96.
Hussein, Ebtissam, H. A.; S. S. Adawy; S. E. M. E. Ismail and H. A. El-Itriby (2005). Molecular characterization of some Egyptian date palm germplasm using RAPD and ISSR markers. Arab J. Biotech., 8 (1): 83-98.

Khadivi-Khub, A; Z. Zamani and N. Bouzari (2008). Evaluation of genetic diversity in some Iranian and foreign sweet cherry cultivars by using RAPD molecular markers and morphological traits. Hortic. Environ. Biotechnol. 49: 188196.

Levi, A. and L. J. Rowland (1997). Identifying blueberry cultivars and evaluating their genetic relationships using randomly amplified polymorphic DNA (RAPD) and simple sequence repeat (SSR) anchored primers. J. Amer. Soc. Hort. Sci., 122: 74-78.

Mansour, A.; H. M. Ismail; M. F. Ramadan and G. Gyulai (2009). Variations in tomato (Lycopersicon esculentum) cultivars grown under heat stress. J. Verbr. Lebensm., 4: 118-127.

Mansour, A.; Jaime A. T. da Silva; S. Edris and Rania A. A. Younis (2010). Comparative Assessment of Genetic Diversity in Tomato Cultivars using IRAP, ISSR and RAPD Molecular Markers. Genes, Genomes and Genomics, 4(1): 41-47.

Mukherjee, A.; B. Sikdar; B. Ghosh; A. Banerjee; E. Ghosh; M. Bhattacharya and S. C. Roy (2013). RAPD and ISSR analysis of some economically important species, varieties, and cultivars of the genus Allium (Alliaceae). Turk. J. Bot., 37: 605-618.

Nagaoka, T. and Y. Ogihara (1997). Applicability of inter-simple sequence repeat polymorphisms in wheat for use as DNA markersin comparison to RFLP and RAPD markers. Theor. Appl. Genet., 94: 597-602.

Nagy, E.; G. Gyulai; Z. Szabo; Z. Hegyi and L.C. Marton (2003). Application of morphological descriptions and genetic markers to analyse polymorphism and genetic relationship in maize. Acta Agronomia Hungarica, 51(3): 257-265.

Nei, M. and W. H. Li (1979). Mathematical model for studying genetic variation in terms of restriction endonucleases. Proc. Natl. Acad. Sci., USA, 76: 5269-5273.

Nevo, E.; E. Golenberg; A. Beilies; A. H. D. Brown and D. Zohary (1982). Genetic diversity and environmental associations of wild wheat. Triticum diococcoides in Israel. Theor. Appl. Genet. 62: 241-254.

Nikoumanesh, K; A. Ebadi; M. Zeinalabedini and Y. Gogorcena (2011). Morphological and molecular variability in some Iranian almond genotypes and related Prunus species and their potentials for rootstock breeding. Sci. Hortic. 129: 108118.

Parsons, B. J.; H. J. Newbury; M. T. Jackson and B. V. FordLloyd (1997). Contrasting genetic diversity relationships are revealed in rice (Oryza sativa L.) using different marker types. Molecular Breeding, 3: 115-125.

Powell, W.; M. Morgante; C. Andre; M. Hanafey; J. Vogel S. Tingey and A. Rafalski (1996). The comparison of RFLP, RAPD, AFLP and SSR (microsatellite) markers for germplasm analysis. Mol. Breed., 2: 225-238.

Prevost, A. and M. J. Wilkinson (1999). A new system for comparing PCR primers applied to ISSR fingerprinting of potato cultivars. Theor. Appl Genet., 98: 107-112.

Rizkalla, A.; B. A. Hussien; A. M. F. Al-Ansary; J. E. Nasseef and Mona H. A. Hussein (2012). Combining Ability and Heterosis Relative to RAPD Marker in Cultivated and Newly Hexaploid Wheat Varieties. Australian J. of Basic and Applied Sciences, 6(5):215-224. 
Roldan-Ruiz, I.; F. A. Van Eeuwijk; T. J. Gilliland; P. Dubreuil; C. Dillmann; J. Lallemand; M. DeLoose and C. P. Baril (2001). A comparative study of molecular and morphological methods of describing relationships between perennial ryegrass (Lolium perenne L.) varieties. Theor. Appl. Genet. 103:1138-1150.

Sant, V. J.; A. G. Patankar; N. D. Sarode; L. B. Mhase; M. N. Sainani; R. B. Deshmukh; P. K. Ranjekar and V. S. Gupta (1999). Potential of DNA markers in detecting divergence and in analysing heterosis in Indian elite chickpea cultivars. Theor. Appl. Genet., 98:1217-1225.

Sneath, P. H. A. and R. R. Sokal (1973). Numerical Taxonomy: the principles and practice of numerical classification. San Francisco, Freeman,188-308.

Srinivasan, T.; P. Nagarajan; N. Senthil; R. Gnanam and V. Ponnuswami (2013). DNA fingerprinting in Tomato (Lycopersicon esculentum Mill.) germplasm accessions using molecular markers. International Journal of Integrative Biology, 14(2):86-95.

Tanksley, S. D.; M. W. Ganal; J. P. Prince; M. C. Devicente; M. W. Bonierbale; P. Broun; T. M. Fulton; J. J. Giovannoni; S. Grandillo; G. B. Martin; R. Messeguer; J. C. Miller; L. Miller; A. H. Paterson; O. Pineda; M. S. Roder; R. A. Wing; W. Wu and N. D. Young (1992). High Density Molecular Linkage Maps of the Tomato and Potato Genomes. Genetics,132(4): 1141-1160.
Tanyolac, B. (2003). Inter-simple sequence repeat (ISSR) and RAPD variation among wild barley (Hordeum. vulgare subsp. spontaneum) populations from west Turkey. Genetic Resources and Crop Evolution, 50(6): 611-614.

Vaillancourt, R. E.; B. M. Potts; M. Watson; P. W. Volker; G. R. Hodge; J. B. Reid and A. K. West (1995). Detection and prediction of heterosis in eucalyptus globules. Forest Genetics, 2(1):11-19.

Weising, K.; R. G. Atkinson and R. C. Gardner (1995). Genomic fingerprinting by microsatellite-primed PCR: A critical evaluation. PCR Meth. Genome Res., 4: 249-25.

Williams, J. G. K.; A. R. Kubelk; K. J. Livak; J. A. Rafalski and S. V. Tingey (1990). DNA polymorphisms amplified by arbitrary primers are useful as genetic markers. Nucl. Acid Res, 18: 6231-6235.

Yadav, K.; Singh, B. D., Srivastava, C. P., Chand, R. and A. Yadav (2010). Analysis of genetic divergence in pea (Pisum sativum L.) using quantitative traits and RAPD markers. Indian Journal of Genetics, 70 (4): 363-369.

Zietkiewicz, E; A. Rafalski and D. Labuda (1994). Genome fingerprinting by simple sequence repeat (SSR)-anchored polymerase chain reaction amplification. Genomics, 20:176-183.

\section{تقينم التتوع الجزئيى والمظهرى وعلاقته بقوة الهجين فى بعض سلالات الطماطم تحث ظروف مناخية مختلفة

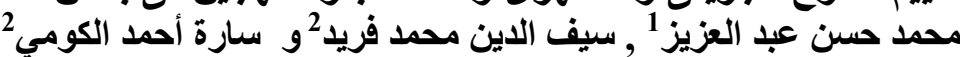

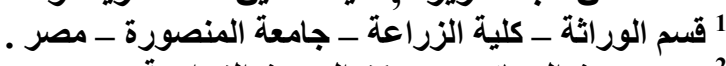

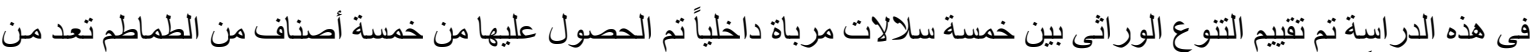

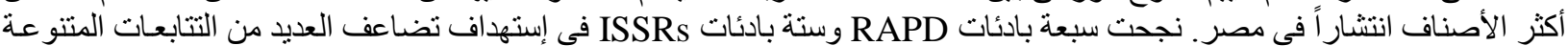

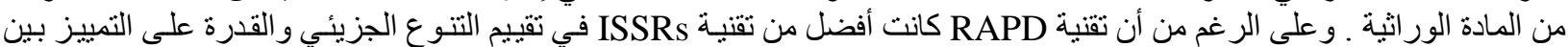

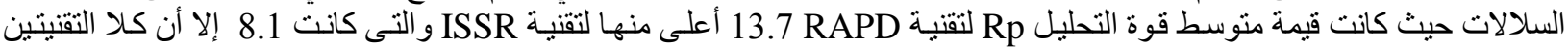

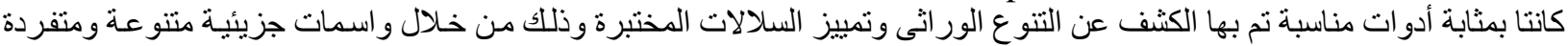

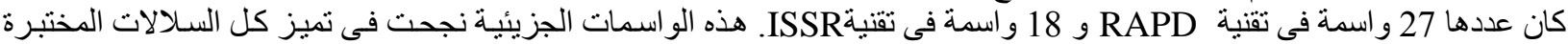

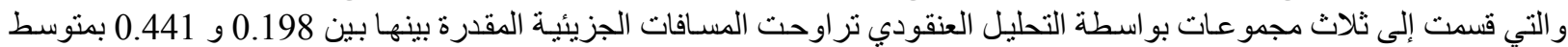

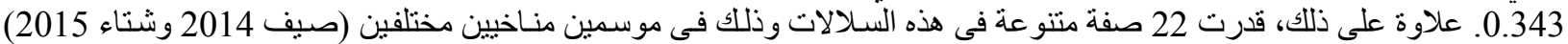

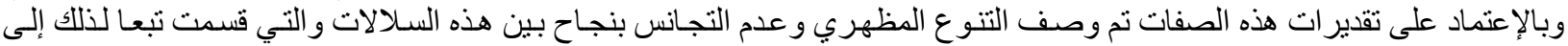

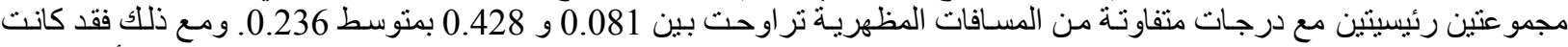

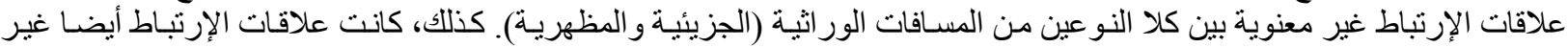

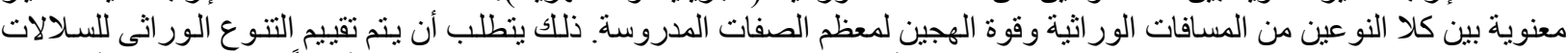

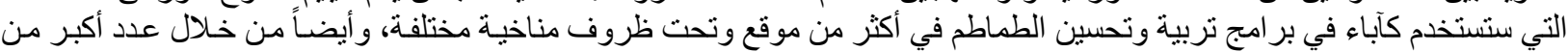

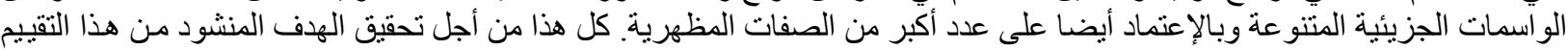

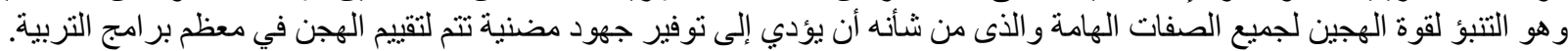

